\title{
Carcinization in the Anomura - fact or fiction? II. Evidence from larval, megalopal and early juvenile morphology
}

\author{
Patsy A. McLaughlin ${ }^{1}$, Rafael Lemaitre ${ }^{2} \&$ Christopher C. Tudge ${ }^{2}$ \\ ${ }^{1}$ Shannon Point Marine Center, Western Washington University, 1900 Shannon Point Road, Anacortes, \\ Washington 98221-9081B, U.S.A ${ }^{2}$ Department of Systematic Biology, National Museum of Natural History, \\ Smithsonian Institution, P.O. Box 37012, Washington, D.C. 20013-7012, U.S.A.
}

Keywords: Carcinization, Anomura, Paguroidea, Lithodidae, Paguridae, Lomisidae, Porcellanidae, larval, megalopal and early juvenile morphology, pleonal tergites

\begin{abstract}
In this second of a two-part series, carcinization in the Anomura has been reviewed from early juvenile, megalopal, and larval perspectives. Data from megalopal and early juvenile development in ten genera of the Lithodidae have provided unequivocal evidence that earlier hypotheses regarding evolution of the king crab pleon were erroneous. A pattern of sundering, and decalcification has been traced from the megalopal stage through several early crabs stages in species of Lithodes and Paralomis, with supplemental evidence from species in eight other genera. Of major significance has been the attention directed to the marginal plates of the second pleomere, which when separated in lithodids are not homologous with the adult so-called "marginal plates" of the following three tergites. Auxiliary megalopal and early juvenile lithodid data, as well as equivalent data from other paguroids, support the evolutionary direction indicated by lithodid pleonal plate development. Therefore, while carcinization, or development of a crab-like body form, has occurred in the Lithodidae, it has not proceeded from a hermit crab ancestor. Rather the data suggest the reverse, thus effectively refuting the "hermit to king" myth. Brief reviews of data available from the Lomisidae and Porcellanidae support the proposition of independent anomuran carcinization events in these taxa as well. Results of cladistic analysis of megalopal and juvenile data, although somewhat unconventional, do not support the claim of a sister-group relation of the lithodid genera Lithodes and Paralithodes with the pagurid genus Pagurus. Attempts to subject larval phase data to similar analysis were thwarted by the tendency in paguroids, including lithodids, for lecithotrophic development. Additionally, presumed initial and terminal stage deletions disallow the ontogenetic stage homologies required for meaningful phylogenetic results.
\end{abstract}

\section{Contents}

Introduction

Carcinization: an evolutionary reality?
Existing hypotheses $\quad 169$

Developmental data $\quad 170$

Results 177

From hermit to king, or king to hermit? 179

Analysis by Richter \& Scholtz $\quad 179$

Questions of asymmetry. $\quad 180$

Pleopod loss and gain $\quad 181$

Uropod loss and transformation 182

Polarity - or what constitutes a primitive character state? $\quad 182$

Semaphoronts 184

Megalopa/early juvenile characters and character states

Cladistic analyses _..

Lomisoidea $\quad 192$

Porcellanidae $\quad 193$

Megalopal and early juvenile phase 193

Zoeal phase $\quad 194$

Conclusions $\quad 194$

Acknowledgements 196

References 196

\section{Introduction}

In Part I of a review of carcinization (the process of developing a crab-like body form) in the Anomura, McLaughlin \& Lemaitre (1997) provided a historical review of reported instances of this phenomenon and examined evidence provided by adult morphology throughout the Galatheoidea, Hippoidea, Lomisoidea, and Paguroidea (classification of Martin \& Davis 2001), with particular emphasis on the Paguroidea. McLaughlin \& Lemaitre (1997) rejected the traditional concept of pagurid carcinization, which had consistently maintained that the lithodid crab-like body form evolved from a typical shell-dwelling hermit crab ancestor (Boas 1880a, 
b, 1924; Bouvier 1894a, b, 1895, 1897; Borradaile 1916; Wolff 1961; Cunningham et al. 1992; Gould 1992; Richter \& Scholtz 1994). The conclusion reached by McLaughlin \& Lemaitre (1997) was that although the acquisition of a crab-like body form had to be acknowledged, the hypothesis that the evolution of such a form in the Paguroidea had proceeded from a shell-dwelling hermit was fallacious. As an alternative hypothesis, they argued just the reverse, i.e., the lithodid crab-like body form had given rise to the simple hermit crab body form through calcium loss, habitat change and consequential morphological adaptations. Although their original hypothesis was based on characters derived from adult morphology, they suggested that developmental data would support their view. Borradaile (1916) had theorized that carcinization was not simply "happen chance" but rather that certain decapod crustaceans possessed the genetic constituents for carcinization while others did not. Similarly, Cunningham et al. (1992), referring to evidence put forward by MacDonald et al. (1957) stated that heterochronic modifications did not appear until metamorphosis. McLaughlin \& Lemaitre (1997) rationalized that if such was really the case, one might expect that those anomurans destined to exhibit aspects of carcinization would exhibit corollary larval, megalopal and early juvenile attributes possibly similar to those of true crabs.

If carcinization is perceived as the development by an organism of a brachyuran crab-like body form, only three major anomuran taxa need be investigated from the developmental view point, i.e., the monotypic Lomisoidea, the galatheid family Porcellanidae, and the superfamily Paguroidea. Like brachyurans, anomuran larvae most commonly hatch from the parental egg as a zoea, a swimming larval form provided with carapace, rostrum, several pairs of cephalothoracic appendages, antennules, antennae, mandibles, maxillules, maxillae, and first and second maxillipeds, elongate pleon of five pleomeres and a telson (Figs. la, b, e, f ). These larvae usually pass through one or more zoeal stages, during which time a sixth pleomere ordinarily is delineated, uropods most frequently develop, and pleopod buds appear, before a metamorphic molt to the benthonically adapted megalopa (decapodid of Kaestner 1970; Felder et al. 1985; Anger 2001) (Figs.
$1 \mathrm{c}, \mathrm{g}$ ). The megalopa is followed directly by a series of juvenile stages (Figs. 1d, h).

There is ongoing debate among developmentalists as to whether the megalopa is correctly considered the last stage of the larval phase (Williamson 1969, 1982; Gould 1992; Harvey 1998; Clark \& Calazans 1999), a single postlarval stage (Goy \& Provenzano 1978, 1979), or the first stage of the postlarval phase, i.e., preceding the juvenile stages (Lebour 1934; Gurney 1942; Gore 1985; Kaestner 1970; Felder et al. 1985; Paul et al. 1993). Zoeal morphology is dramatically transformed with the molt to the megalopa. The animal assumes a body shape adapted more for walking or crawling than for swimming, although many megalopae at least initially are still quite capable of swimming. However, locomotor functions are transferred to the pleopods and/or the thoracic ambulatory legs, while the maxillipeds, the swimming appendages of the zoea, are converted into feeding appendages. Morphologically, progression from megalopa to young adult, although involving a series of molts, is usually a relatively gradual, and not always a molt controlled, transition.

For many viewing the megalopa as larval, however, the metamorphic molt is interpreted as occurring between the megalopa and the first juvenile stage (Dawirs et al. 1986; Anger 1996; Gebauer et al. 2002; Charmantier et al. 2002). This phenomenon would appear to represent a more physiological than morphological metamorphosis. Harvey (1996) however, reported two metamorphic molts in three species of hermit crabs, the first occurring between the last zoea and the megalopa, and the second occurring between the megalopa and first crab stage. Anger (2001) similarly defined the transition from zoea to megalopa and from megalopa to juvenile as metamorphic. For the purposes of the present discussion, we consider the primary metamorphosis occurring between the last zoea and the megalopa as the focal point, and in our discussion of semaphoronts, we refer to stages subsequent to this metamorphic molt as "postlarval". Additionally, we have elected to use the currently more commonly recognized term megalopa, rather than glaucothoe of numerous earlier authors (Gurney 1942; MacDonald et al. 1957; Kurata 1956; Provenzano 1971', 1978; Bookhout 1972; Gore \& Scotto 


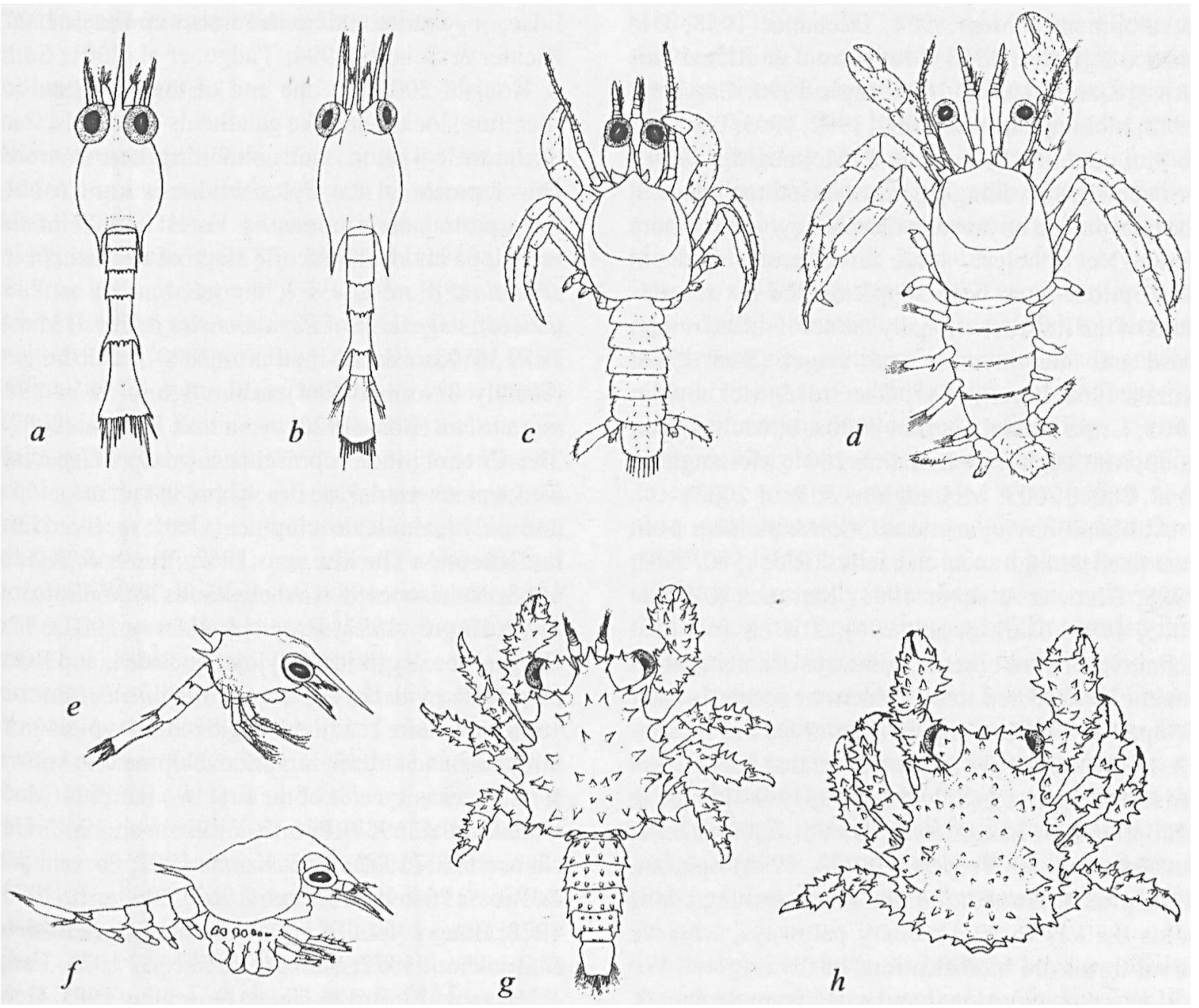

Fig. 1. Larval, megalopal and early juvenile stages of Paguridae (a-d) and Lithodidae (e-h). a-d, Pagurus kennerlyi (Stimpson, 1864): a, zoea I, dorsal view; b, zoea IV, dorsal view; c, megalopa, dorsal view; d, first crab stage, dorsal view. e-h, Lopholithodes mandtii Brandt, 1848: e, zoea I, lateral view; b, zoea IV, lateral view; c, megalopa, dorsal view; d, first crab stage, dorsal view. (a-d, modified from McLaughlin et al. 1989; e, f, modified from Crain \& McLaughlin 2000; g, h, specimens used by Crain \& McLaughlin 2000, (USNM 1006124). Not to scale.

1983; Forest 1987; Nakasone 1988; Gould 1992), decapodid of Kaestner (1970), Felder, et al. (1985), and Anger (2001), or megalop of Clark et al. (1998), Clark \& Calazans (1999), and Fujita et al. (2002). Our data on development in the monotypic Lomisoidea are restricted to the description of a single zoeal stage of Lomis hirta (Lamarck, 1818) by Cormie (1993) and information obtained by Provenzano (unpublished) and made available to the authors. Knowledge of larval development in the galatheoid family Porcellanidae is much more ex- tensive; although the majority of these descriptions have been limited to zoeal and megalopal developmental sequences. However, a few studies importantly have included partial to complete descriptions of at least the first crab stage (Shenoy \& Sankolli 1971; Paul et al. 1993; Albornoz \& Wehrtmann 1996; Brossi-Garcia \& Guimarães Moreira 1996; Wehrtmann et al. 1996). The data base for shell inhabiting pagurids is considerably larger in terms of larval and megalopal stage descriptions, but relatively limited in documentation of early juvenile 
development (Forest 1954; Dechancé 1958; Dechancé \& Forest 1958; Provenzano \& Rice 1966; Brossi-Garcia 1987b, 1988; Ingle 1990; Carvacho 1988; McLaughlin et al. 1989, 1992, 1993; Lemaitre \& McLaughlin 1992; Crain \& McLaughlin 1994). For non-shell dwelling pagurids, including lithodids, the information on juvenile morphology is even more finite. Nevertheless, some larval and megalopal descriptions have been supplemented by descriptions of the first, occasionally the second, and rarely, third and later juvenile crab stages (Sato 1958; Kurata 1964; Forest, 1987; Gherardi \& McLaughlin 1995; Crain \& McLaughlin 2000a, b; McLaughlin 2000; McLaughlin \& Lemaitre 2001; McLaughlin, et al. 2001, 2003; McLaughlin \& Paul 2002).

Although phylogenetic relationships have been examined through zoeal characters (Rice 1980, 1983, 1988; Clark \& Webber 1991; Marques \& Pohle 1995, 1998; Clark et al. 1998), it is obvious that definitive, or even obscure, pathways of carcinization cannot be expected to be evident in zoeae. In fact, Wolpert (1994) has argued that larvae are incapable of evolution, per se; however, that view is not universally shared (Schminke 1981; Walossek \& Müller 1990; Fukuda 1995; Dahms 2000). Direct development, in Wolpert's $(1990,1994)$ opinion, is the primitive condition; the imago (young adult) holds the key to evolutionary pathways, whereas larval forms are modifications of the original. We will examine megalopal and early juvenile stages, as much as current available data permit, to determine if pathways of carcinization can be detected, and will examine selected zoeal characters to see if additional supportive information can be obtained. We begin with the Paguroidea, not only because more data are available for zoeal, megalopal and early juvenile development in this group, but because it is the relationship between lithodids and pagurids, and the potential carcinization in the former that are of primary concern.

The Paguroidea provides a wide range of evolutionary enigmas that have been overlooked, incorrectly analyzed, and/or poorly investigated. Seven families currently are recognized: the Pylochelidae, Coenobitidae, Diogenidae, Paguridae, Pylojacquesidae, Parapaguridae, and Lithodidae. The Pyloche- lidae, or symmetrical hermit crabs (cf. Forest 1987; Richter \& Scholtz 1994; Tudge, et al. 2001; Saito $\&$ Konishi 2002), at one end of the superfamilial spectrum, look more like galatheids or aeglids, than the more common shell-inhabiting hermit crabs. Development in the Pylochelidae is known only from partial descriptions by Forest (1987) of the megalopa and first juvenile stage of Pomatocheles stridulans Forest, 1987; the account of an "advanced" stage larva of Pomatocheles jeffreysii Miers, 1879 by Konishi \& Imafuku (2000); and the just recently described first zoeal stage of Pylocheles mortensenii (Boas, 1926) by Saito \& Konishi (2002). The Coenobitidae represents a group of specialized, semiterrestrial species, whose larval, megalopal and early juvenile developments have received limited attention (Provenzano 1962; Reese \& Kinzie 1968; Nakasone 1988; Al-Aidaroos \& Williamson 1989; Harvey 1992; Brodie \& Harvey 2001). The Diogenidae, Paguridae, Pylojacquesidae, and Parapaguridae (with the exception of Probeebei Boone, 1926) are more readily recognized as typical hermit crabs and at least larval development is known for numerous species of the first two families (MacDonald et al. 1957; Pike \& Williamson 1960; Dechancé 1961, 1962, 1963; Kurata 1962; Provenzano \& Rice 1964; Provenzano 1967, 1968a, b, 1971, 1978; Hong 1969, 1981; Bookhout 1972; Goldstein \& Bookhout 1972; Sankolli \& Shenoy 1975; Lang \& Young 1977; Brossi-Garcia \& Hebling 1983; Gore \& Scotto 1983; Baba \& Fukuda 1985; Brossi-Garcia 1987a; Konishi \& Quintana 1987, 1988; McLaughlin \& Gore 1988, 1992; McLaughlin et al. 1989, 1991a, b, 1993; Siddiqui et al. 1991, 1993; Shenoy \& Sankolli 1993. At the opposite end of the spectrum, the Lithodidae look superficially like true crabs. Because of their commercial importance, development, particularly zoeal and megalopal, in several species has been investigated extensively (Sars 1890; MacDonald et al. 1957; Kurata 1956, 1960, 1964; Sato 1958; Miller \& Coffin 1961; Hart 1965; Hoffman 1968; Campodonico 1971; Campodonico \& Guzmán 1981; Haynes 1982, 1984, 1993; Konishi 1986; Konishi \& Taishaku 1994; Shirley \& Zhou 1997; Crain \& McLaughlin 2000a, b; Kim \& Hong 2000; McLaughlin et al. 2001, 2003). 


\section{Carcinization: an evolutionary reality?}

\section{Existing hypotheses}

The term carcinization was first coined by Borradaile (1916), but a relationship between hermit crabs and lithodids had been proposed much earlier by H. Milne Edwards (1837), De Haan (1849), Boas (1880a, b), and Bouvier (1894a, b, 1895, 1897). While H. Milne Edwards (1837) and De Haan (1849) related the two groups through the coenobitids, Boas (1880a, b) and Bouvier (1894a, b, 1895, 1897) hypothesized a link between lithodids and the genus Pagurus Fabricius, 1775 (as Eupagurus Brandt, 1851). Boas (1880b) specifically compared mouthparts, gill structure, musculature of the chelipeds, and pleonal tergites of a pagurid and a lithodid and concluded that of all genera known at the time, the Lithodidae were closest to the genus Pagurus. In a subsequent study, Boas (1924), disputed the transitional role of the Hapalogastrinae in Bouvier's (1894a, b, 1895 1897) theory of pleomere plate evolution that had been put forth in the interim. Boas $(1880 \mathrm{~b}, 1924)$ was of the opinion that the membranous condition and plate reduction seen in Pagurus tergites represented decalcification of the median regions, which he attributed to an evolution from the ancestral form of early reptant decapods. Boas explained the differences seen in the well-calcified second tergite of Paralithodes brevipes (H. Milne Edwards \& Lucas, 1841) (as Lithodes Latreille, 1806) simply as a subsequent reinforcement of the membranous area between the two tergal plates of Pagurus and with the addition of newly developed marginal plates. He equated the median regions of tergites 3-5 to the membranous areas between the tergites of Pagurus; marginally on each a row of little calcified plates had formed. His biggest earlier difficulty had been explaining the presence of paired first pleopods in females of Paralithodes Brandt, 1848 (as Lithodes). However, when he learned of certain pagurid genera that also had female paired first pleopods, he placed the lithodid ancestor in or close to the pagurid genera Nematopagurus A. Milne-Edwards \& Bouvier, 1892 and/ or Pylopagurus A. Milne-Edwards \& Bouvier, 1892, rather than Pagurus.

Although both Boas (1880a, b, 1924) and Bouvier (1894a, b, 1895, 1897) arrived at the same conclusion regarding the evolution of the Lithodidae from the Paguridae, Bouvier's evolutionary concept was quite different. His hypothesis provided a most explicit pathway for the evolutionary transformation of a membranous hermit crab pleon to that of a heavily calcified and apparently plated lithodid pleon. McLaughlin \& Lemaitre (1997) reviewed Bouvier's $(1894 a, b, 1895,1897)$ carcinization theory in depth. Nonetheless, it is helpful to reiterate the particularly pertinent aspects of that transformation in light of what is now known about the actual transition. In Bouvier's view (Fig. 2 ), the membranous pleon of an ancestral hermit crab (Fig. 2a) progressively was invaded by calcified nodules, and ultimately these nodules fused to form calcified plates. Initial fusion and plate formation occurred principally in the first and second tergites (Fig. 2b), with the third through fifth invaded first with granules and successively with increasingly larger and more numerous nodules (Fig. 2c). Gradually, over evolutionary time, the plates of the first and second tergites fused completely (Figs. 2e, g), while the initial fusion of invading nodules in the third through fifth tergites formed the lateral and marginal plates (Figs. 2d, e). Ultimately the median nodules also fused to form solid plates (Figs. $2 f, g)$.

More recent authors similarly have pointed to the close evolutionary relationship between the Paguridae and Lithodidae, but none have been as definitive in tracing pathways. Borradaile (1916) and Wolff (1961), for example, while deriving the lithodids from a Pagurus-like ancestor, cited other examples of quasi-carcinization (e.g., Porcellanopagurus Filhol, 1885a, Birgus Leach, 1815, and Probeebei) as convergent events within the Paguroidea. Cunningham et al. (1992), strongly supported by Gould (1992), not only evolved two lithodid genera from Pagurus, but also these authors, in a clear presumption of monophyly, proposed that those lithodid genera were so closely allied to the latter genus that they should be taxonomically included in it. Richter \& Scholtz (1994) did not suggest a specific pagurid ancestor. They simply concluded that the Lithodidae represented a group of secondarily free-living "asymmetrical" hermit crabs. However, they did point to a series 
of characters they believed supported their conclusion. A decidedly different pathway, which suggested that alternatives to shell dependence led to carcinization, was proposed by Blackstone (1989) and reiterated by Gherardi $(1995,1996 b)$. In yet another, potentially controversial hypothesis, von Sternberg (1996) adapted Sluys' (1989) "rampant process of parallelism" in proposing a homeotic gene model of c-loci regulatory elements to account for carcinization in the Anomura. Most recently, Morrison et al. (2002), using mitochondrial gene rearrangement, purportedly confirmed the Cunningham et al. (1992) hypothesis.

\section{Developmental data}

In a series of studies of several lithodid genera, Crain \& McLaughlin (2000a, b), McLaughlin \& Lemaitre (2001), McLaughlin et al. (2001, 2003 ), and McLaughlin \& Paul (2002) have demonstrated what morphological changes actually do occur in the pleonal tergites during the transition from the megalopa through early lithodid crab stages. In the megalopae of all species that have been investigated, the six pleomeres are represented dorsally by six undivided tergites. These tergites are typically chitinous, as in many, but not all pagurids, in the genera Hapalogaster Brandt, 1850, Oedignathus Benedict, 1895, and Placetron Schalfeew, 1892, of the lithodid subfamily Hapalogastrinae, and in the genera Lithodes, one species of Paralithodes, and Cryptolithodes Brandt, 1848, of the subfamily Lithodinae. Alternatively, these tergites may be at least weakly calcified as in the Hapalogastrinae genus Acantholithodes Holmes, 1895, and in the Lithodinae genera Lopholithodes Brandt, 1848, $\mathrm{Pa}$ ralithodes (one species), Phyllolithodes Brandt, 1848, and Paralomis White, 1856. As may be seen in the following summation, the evidence presented by the above cited authors confirms McLaughlin \& Lemaitre (1997), who postulate changes in the lithodid pleon resulted at least initially from division rather than fusion. The most complete data are available for two species of the genus Lithodes and one of Paralomis, with more limited information for species of eight other genera. Although the patterns of changes during the early crab stages are similar, these changes do not appear to occur at the same rate among or even within genera.

Lithodes aequispinus Benedict, 1895 (Figs. 3M$\mathrm{C} 12$ ). The six megalopal tergites are chitinous and distinct (Fig. 3M). Accompanying the molt to crab stage 1 is pronounced pleonal flexion. Tergites of the first, second and sixth pleomeres remain chitinous or become weakly calcified. Tergite one is distinct and undivided, whereas, tergite two now has the marginal plates partially to entirely separated. Tergite three also shows complete or partial separation of weakly calcified marginal plates (Fig. $3 \mathrm{C} 1$ ), as identified by the marginal spines of megalopa. Similar divisions of the marginal plates of tergites four and five are indicated by partial to complete sutures. The lateral plates of tergites three to five are faintly delineated, and sometimes slightly calcified. The median regions remain chitinous or become thinly membranous; megalopal spines are sometimes still present, but more frequently only indicated by setal projections. With the molt to crab stage 2 , tergites one, two, and six, as well as the telson are moderately well calcified. The first and second tergites are generally unchanged except for armature. Tergites three to five are entirely membranous medially but have irregular lateral plates delineated and weakly to moderately well-calcified (Fig. 3C2); similarly well calcified marginal plates are usually separated from the lateral plates, at least on pleomeres three and four. Crab stage 3 is ac-

Fig. 2. Summary of stages in the hypothetical transformation of the pleon from a pagurid ancestor to a lithodid as proposed by Bouvier (1894a, b, 1895, 1897), showing membranous (green) and calcified (yellow) portions, and calcified nodules (pink): a, pagurid ancestor, dorsal view; b, Hapalogaster Brandt, 1850, dorsal (top) and ventral (bottom) views; c, Neolithodes A. Milne-Edwards \& Bouvier, 1894, posterior (top) and ventral (bottom) views; d, Lithodes Latreille, 1806, posterior (top) and ventral (bottom) views; e, Lopholithodes Brandt, 1848, posterior (top) and ventral (bottom) views; f, Paralomis White, 1856, ventral view; g, Cryptolithodes Brandt, 1848, ventral view. All pleons are of adult males. Abbreviations: ac, accessory plates; la, lateral plates; m', "pièces marginales" of Bouvier (1897: 42, figs 5-9); Me, unpaired median plate; t, telson. Numbers indicate pleomeres 1-6. (Modified from Bouvier 1897, and McLaughlin \& Lemaitre 2001). Not to scale. 
PAGURID

ANCESTOR

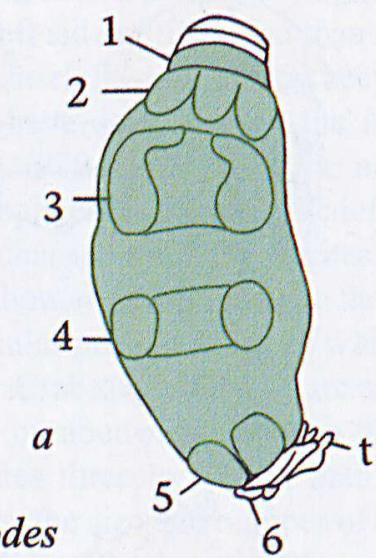

Hapalogaster

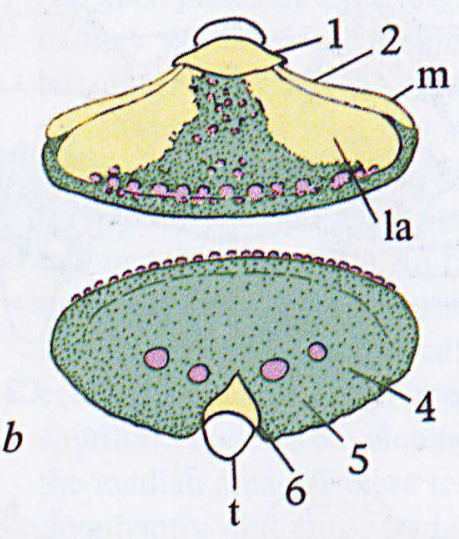

Neolithodes

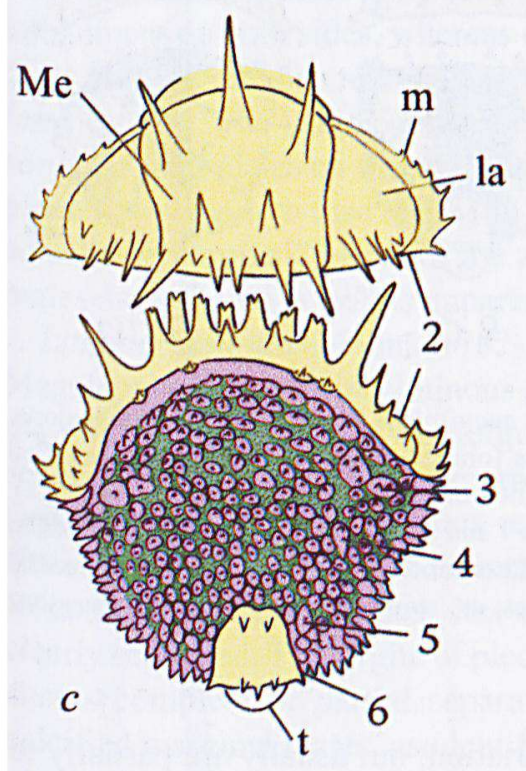

Paralomis

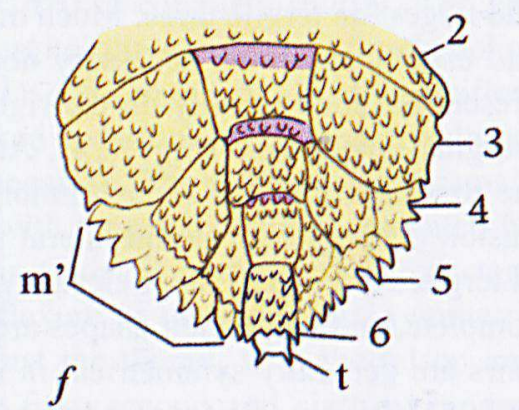

Lithodes

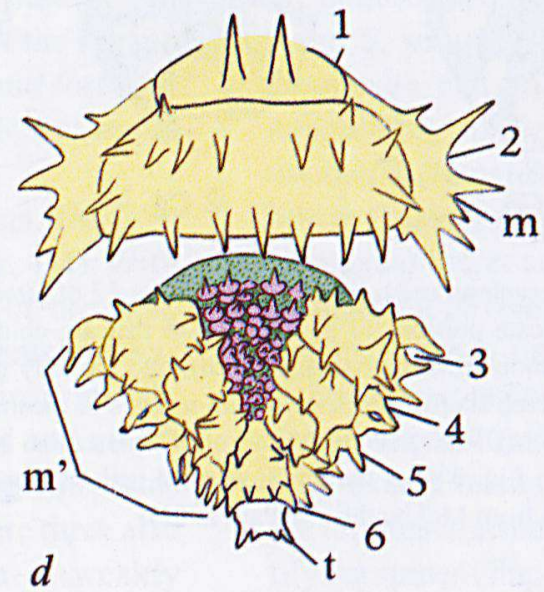

Lopholithodes

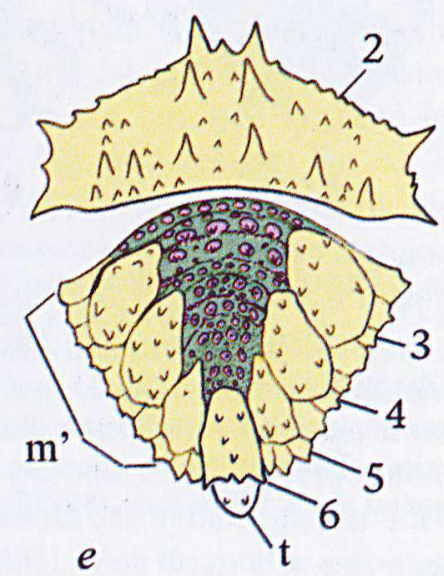

\section{Cryptolithodes}

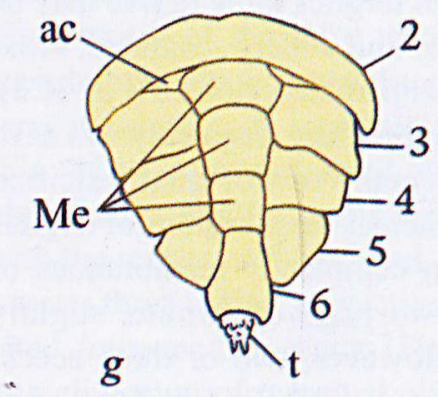




\section{Lithodes aequispinus}

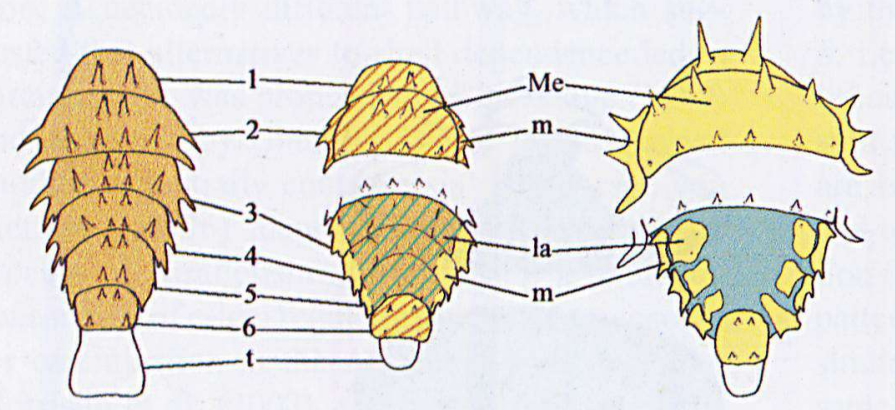

M

$\mathrm{C} 1$
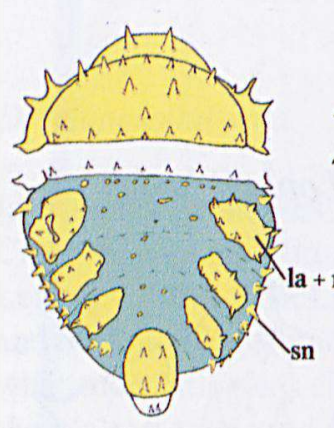

$0^{\top} \mathrm{C} 5$
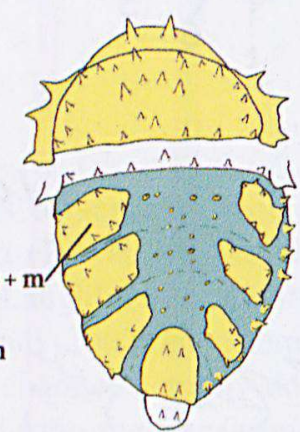

우 $\mathrm{C} 5$
$\mathrm{C} 2$

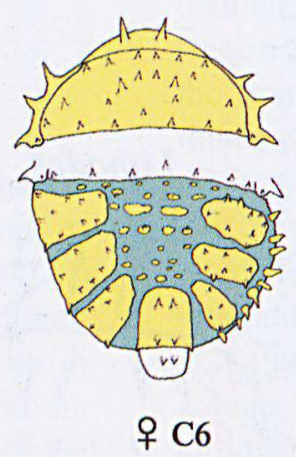

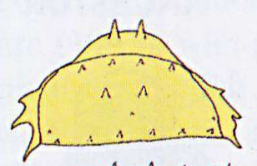
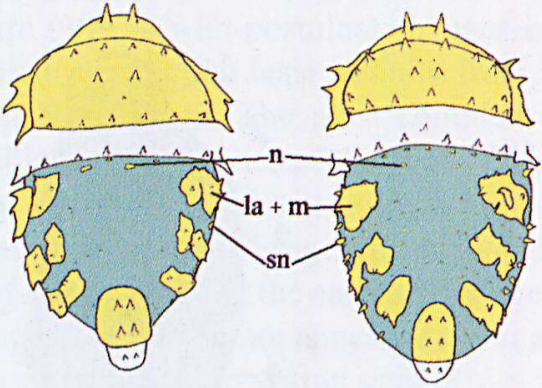

C3

C4

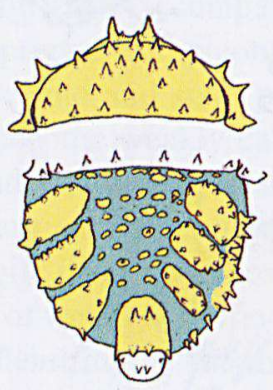

우 $\mathrm{C} 7$

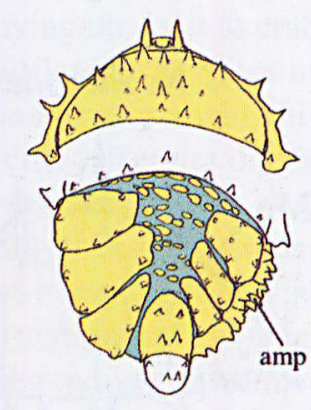

우 $\mathrm{C} 12$

Fig. 3. Pleonal tergite development of megalopa and juveniles to crab stage 12 of Lithodes aequispinus Benedict, 1895: M, megalopa; $\mathrm{C} 1-\mathrm{C} 7+\mathrm{C} 12$, crab stages. Colors indicate portions of pleomeres 1-6 that are chitinous (orange), membranous (green), calcified (yellow), variably chitinous or membranous (orange hatched green), and variably calcified or chitinous (yellow hatched orange). Megalopa pleon shown in dorsal view; crab stages each shown with tergites of pleomeres 1 and 2 (top), dorsal view, separated from those of pleomeres 3-6 and telson (bottom), ventral view. Views of pleomeres 3-6 and telson in crab stages include part of second tergite (uncolored). Abbreviations as in Fig. 3 with the addition of: n, calcified nodules; sn, spiniform nodules; amp, accessory marginal plates. Not to scale. (Modified from McLaughlin \& Paul 2002).

companied by increased calcification in tergites one, two and six, as well as changes in strength and numbers of spines. More importantly, the lateral and marginal plates of tergites three to five may be undivided, completely and widely separated, separated but contiguous, or partially rejoined (Fig. 3C3). The median area of tergite three frequently will have two or sometimes an entire row of small calcified nodules anteriorly, whereas these regions of tergites four and five remain completely membranous or show only one or two pairs of minute, slightly calcified granules. However, two or three accessory, and usually spinose, calcified nodules often can be detected developing in the marginal integument on one or both sides. At crab stage 4, the lateral and marginal plates of tergites three to five exhibit considerable variation, but usually are partially to completely rejoined. The median area of each tergite generally has a few calcified nodules, most numerous and largest on tergite three. Much more prominent and usually spiniform accessory nodules are now present on both, or only on the right sides of the marginal integument (Fig. 3C4). At crab stage 5, the first indications of sexual dimorphism appear. Fusion of the marginal and lateral plate elements of tergites three to five in males may or may not be complete, and while their shapes are irregular, the pairs are generally symmetrical in size (Fig. 3C5 male). Accessory spiniform nodules can be observed developing in the marginal integument on both sides of the pleon. The median areas remain membranous but with a slight increase in the number of 
calcified nodules. At this stage in females, the usually, now entirely fused lateral and marginal plates of tergites three to five are somewhat to appreciably larger on the left side of the pleon than on the right. However on the right side, several accessory spiniform nodules have developed in the integumental margin (Fig. 3C5 female). Similar nodular development is completely lacking on the left side. As in males, the median areas of these tergites, while still membranous, show slight increases in the number of calcified nodules present, some of which are minutely spinulose. Crab stages 6 and 7 are marked by increases in the number of nodules on the median areas of tergites three to five in both sexes (Fig. 3C6). In males, the size and number of accessory spiniform nodules increases in the marginal integument on both sides, whereas development of these nodules remains restricted to the right side in females (Fig. 3C7). By crab stage 12, the accessory marginal plates on the right side of the female pleon have begun to fuse (Fig. $3 \mathrm{Cl2}$ ) and form the so called "marginal" plates of the adult, but in the males such fusion is not as apparent.

Lithodes santolla (Molina, 1782) (Figs. 4M-C5). Megalopal tergites all are chitinous (Fig. 4M). With the molt to crab stage 1 , the tergites of the first, second and sixth pleomeres become weakly calcified, whereas the other tergites remain primarily chitinous. The first tergite is distinct and undivided. In contrast, the second now has marginal plates clearly separated. The tergite of pleomere three also shows complete or partial separation of weakly calcified marginal plates, as identified by the marginal spines of the megalopa. Similar divisions of marginal plates of the fourth and fifth tergites are indicated by partial to complete sutures. The lateral plates of tergites three to five are faintly delineated (Fig. $4 \mathrm{Cl}$ ), and sometimes slightly calcified, but with marked reduction of the posterodorsal spines of the megalopa. The median regions remain chitinous but with megalopal spiries indicated by setal projections. Changes accompanying crab stage 2 include the flexure of the triangular, symmetrical pleon against the thorax, with the telson and tergites of the first, second and sixth pleomeres moderately well calcified. The first and second tergites remain unchanged except for armature; whereas, the lateral plates of tergites three to five are clearly delimited, weakly calcified, and usually each now has two or three small spines. The marginal plates of these tergites are still delineated or now partially or completely refused with the laterals (Fig. 4C2). The median areas remain simply chitinous but with few spines of the megalopa distinguishable as low, sometimes weakly calcified, tiny nodules or spinulose protuberances, each with one or two short setae. In crab stage 3 , the fused marginal and lateral plates of tergites three to five have become moderately calcified, while the adjacent, chitinous marginal integument now has a few spiniform nodules developing (Fig. 4C3). Although the median areas of these tergites still remain predominantly chitinous, nodular areas of calcification are often more definitive here. During crab stages 4 and 5, the median areas exhibit increases in the number of calcified nodules, sometimes with the nodules fusing to form transverse rows. At crab stage 5, seжual dimorphism is evident, with the composite marginal and lateral plates increasing appreciably in size on the left side in some individuals (females) (Fig. 4C5 female) but not in others (males) (Fig. 4C5 male). Additionally, the increasing larger accessory nodules in the marginal integument develop on both the right and left sides (males) or only on the right side (females).

Paralomis granulosa (Jacquinot, in Hombron \& Jacquinot, 1846) (Figs. 4M-C5): All six megalopal tergites and telson are well calcified, and each of the tergites is armed with one or more pairs of identifying spines (Fig. 4M). With the molt to crab stage 1 , the pleon may or may not be strongly flexed against cephalothorax (not illustrated as flexed); the tergites of the first and second pleomeres are entire, distinct or partially to almost entirely fused. The tergites of the third through fifth pleomeres each has developed partial to complete lateral sutures dividing each into median and lateral plates (Fig. 4C1). At crab stage 2, the tergite of the first pleomere is usually partially to completely fused with the tergite of the second. The lateral plates of tergites three to five, respectively, are entirely separated from median plates (Fig. $4 \mathrm{C} 2$ ), but there is no delineation of marginal plates. In crab stage 3 , the adult condition of fused tergites one and two is complete (Fig. 4C3); still no marginal plates have been delineated on tergites three to five. In crab 
Lithodes santolla
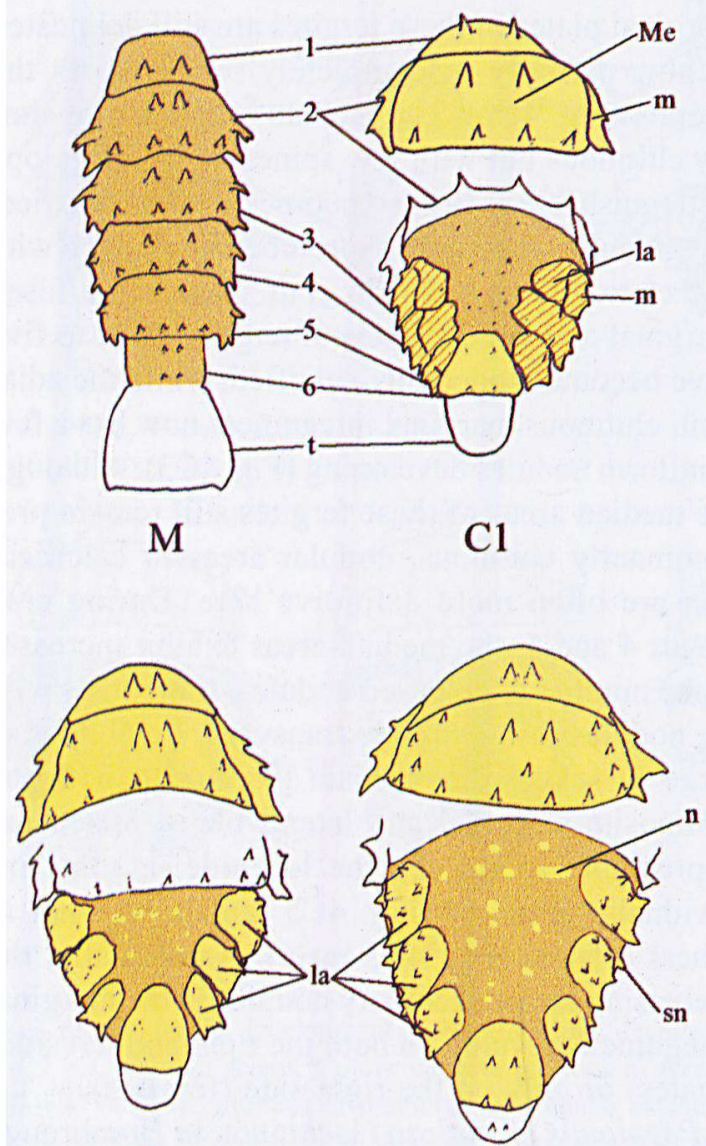

$\mathrm{C} 2$

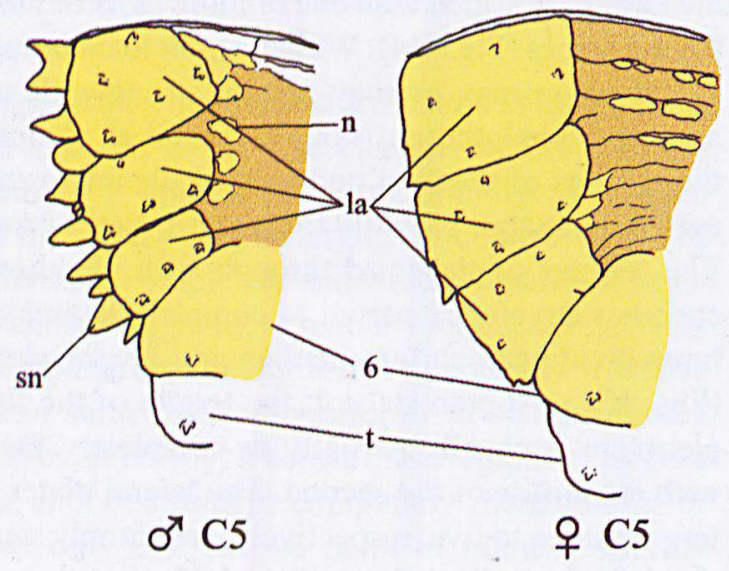

Paralomis granulosa
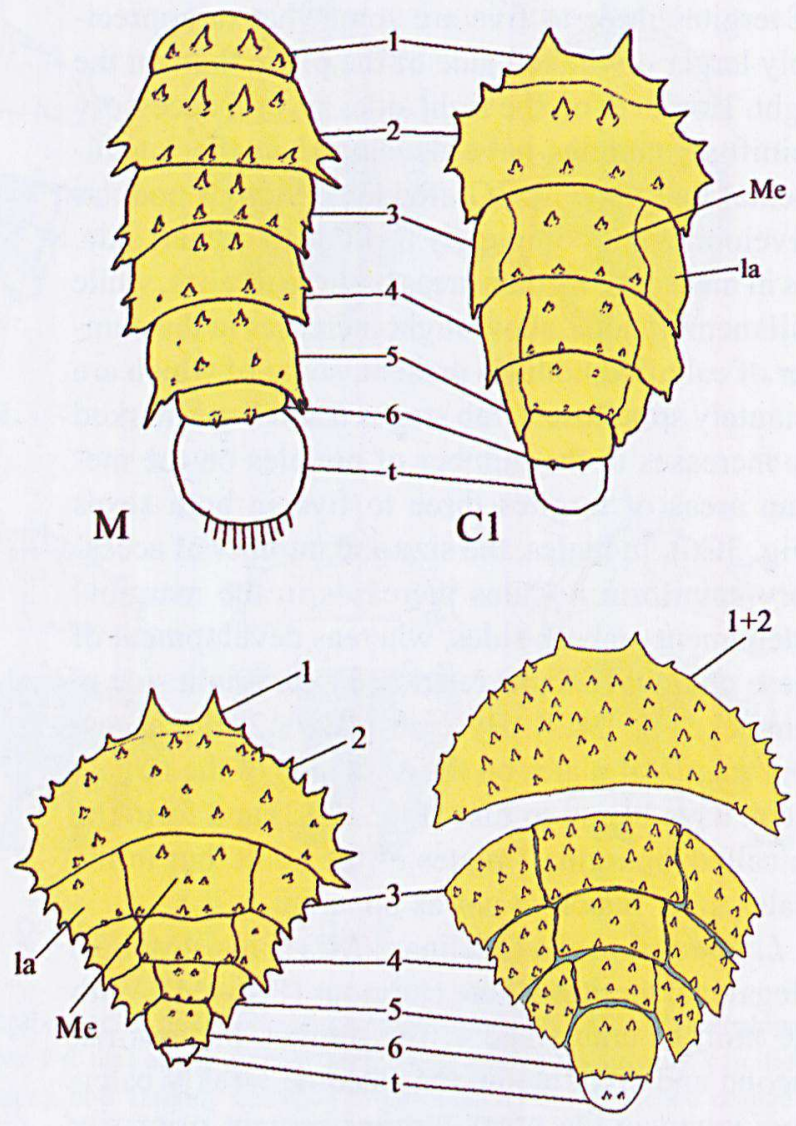

$\mathrm{C} 2$

C3
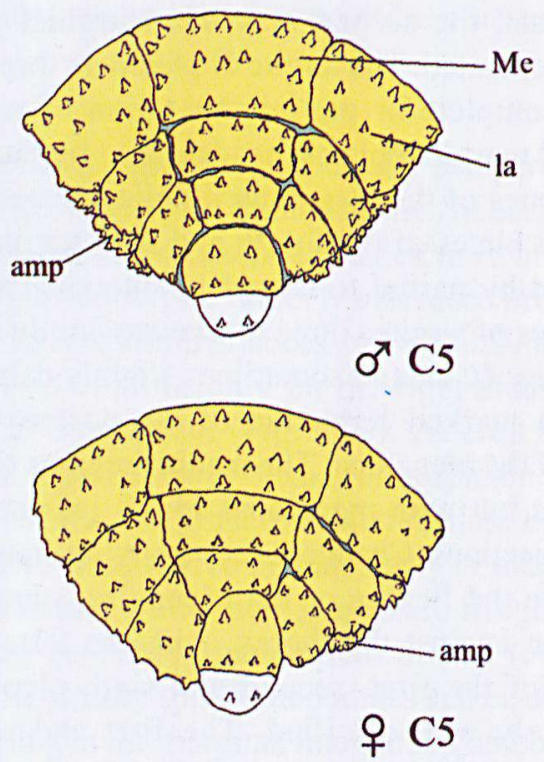
stage 4 there may be the initial early development of accessory, small, calcified nodules in the integumental margins adjacent to the lateral plates of tergites three to five. By crab 5 stage, sexual dimorphism is clearly apparent, with quite small, but well defined accessory marginal plates present on the right side in females (Fig. 4C5 female) and on both sides in males (Fig. 4C5 male). Similarly, the onset of female lateral plate asymmetry is unmistakable, particularly in tergite 5 .

Lopholithodes (Figs. 5M-C2): The megalopa of L. mandtii Brandt, 1848, has the six pleonal tergites represented by individually distinct, moderately calcified plates, each with several identifying spines (Fig. 5M). With the molt to the crab stage 1 , the first and second tergites remain entire; the third through fifth tergites now show incomplete or complete lateral sutures, dividing each tergite into median and lateral plates (Fig. 5C1). The median plates are each provided with spines corresponding to those seen in the megalopa. In crab stage 2 , the first and second tergites fuse, either partially or completely; the third tergite is now divided into one median, two small accessory plates and two lateral plates, all separated by membranous areas (Fig. 5C2). The fourth tergite is now represented by a median and two lateral plates, as is the fifth, although the membranous areas of separations are more apparent in the fourth.

Phyllolithodes (Figs. 5M-adult): Only the megalopal and crab stage 1 of $P$. papillosus Brandt, 1848 have been examined. The six tergites of the megalopa are somewhat calcified, and all are provided with two or more spines (Fig. 5M). With the molt to crab stage 1 , considerable decalcification and division has begun. The median and lateral plates of the second tergite are well separated, and evidence of the presumed upcoming separation of marginal plates is indicated (Fig. 5C1). The fifth tergite is entire, although a weak indication of the presumed separation of a median plate can be observed. The division of the median plate of tergite seen in the adult (Fig. 5 adult) is already indicated in crab stage 1.

Paralithodes (Figs. 5M-adult): The six pleomeres of the megalopa of $P$. brevipes are chitinous (Fig. $5 \mathrm{M})$ and no true spines are developed, but possibly incipient spines are indicated on the first and second tergites by slight protuberances and setae. In contrast, these tergites are very weakly and partially calcified in $P$. camtschaticus Tilesius, 1815 , with very prominent spines present on tergites 1 and 2 and smaller spines on tergites 3-5. With the molt to crab stage 1 in $P$. brevipes, the first, second, and sixth pleonal tergites and telson exhibit integumental calcification. In the first and sixth tergites calcification is complete, whereas calcification of the second is partial to complete. The second tergite also has now partially to completely divided into median, lateral, and marginal plates (Fig. $5 \mathrm{Cl}$ ). Tergites of pleomeres 3-5 remain chitinous; however, indications of lateral and marginal plate divisions are already apparent. Similar tergite division was illustrated by Kurata (1964) for crab stage 1 of $P$. camtschaticus. The decalcification and nodular development of the median plates seen in the adult (Fig. 5 adult) has not begun at the first crab stage in this species.

Cryptolithodes (Fig. 5M-aduit): Megalopal and first crab stages of two species have been examined, C. sitchensis Brandt, 1853 and C. typicus Brandt, 1848. The megalopae of both have unarmed, chitinous tergites (Fig. 5M). Although some flexion in the pleon is apparent in the first crab stage, no marked changes in tergite development have occurred, except for very faint lateral depressions. Clearly the fusion of the first and second tergites and sundering of the third to fifth tergites seen in the adult (Fig. 5adult) proceeds much more slowly in Cryptolithodes.

Acantholithodes (cf. McLaughlin \& Lemaitre 2001, figs. 4a-e): The megalopa of $A$. hispidus (Stimpson, 1860) has weakly calcified tergal plates, each provided with prominent spines. By the first

Fig. 4. Pleonal tergite development of megalopa and juveniles to crab stage 5 of Lithodes santolla (Molina, 1782) and Paralomis granulosa (Jacquinot in Hombron \& Jacquinot, 1846): M, megalopa; C1-C3 + C5, crab stages. For C5 of $L$. santolla, only left half of tergites 3-6 and telson shown. Views of pleomeres 3-6 and telson in crab stages of $L$. santolla include part of second tergite (uncolored). Color-coding and abbreviations as in Figs 2 and 3. Not to scale. (L. santolla, modified from McLaughlin et al. 2001; P. granulosa, modified from McLaughlin et al. 2003). 


\section{Lopholithodes mandtii}

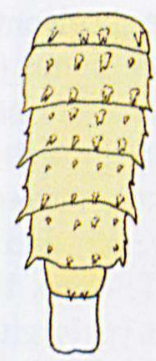

M

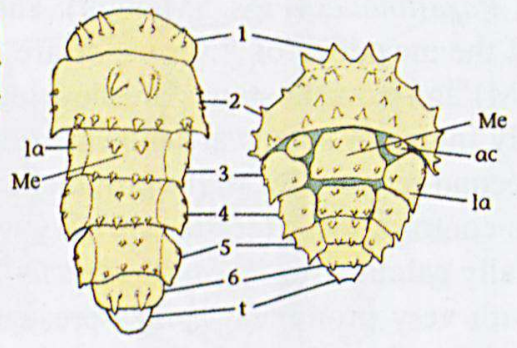

C1

$\mathrm{C} 2$
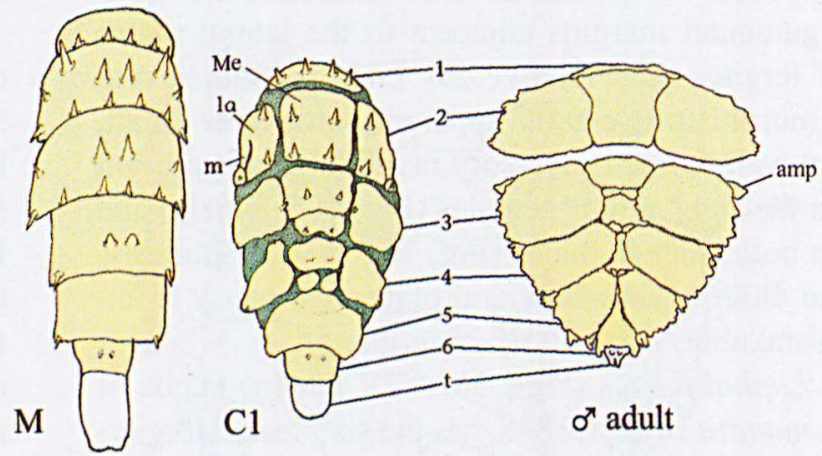

Cryptolithodes sitchensis

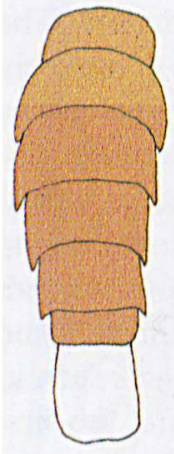

$\mathrm{M}$

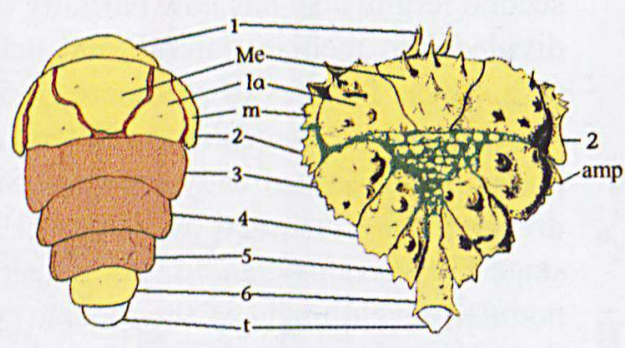

C1

$\sigma^{x}$ adult

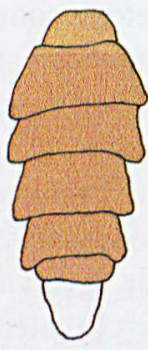

M

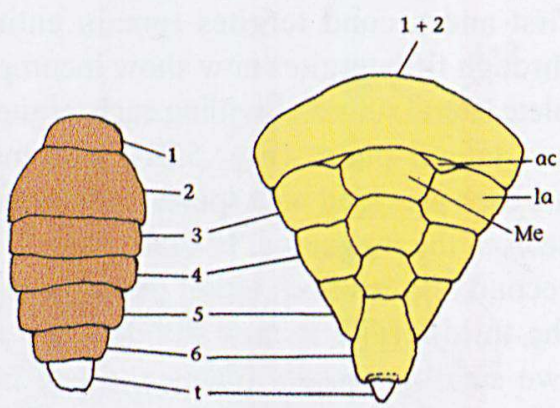

C1 $\sigma^{x}$ adult

Fig. 5. Pleonal development of megalopa and juveniles to crab stage 1 or 2 of Lopholithodes mandiii Brandt, 1848, Phyllolithodes papillosus Brandt, 1848, Paralithodes brevipes H. Milne Edwards \& Lucas, 1841, and Cryptolithodes sitchensis Brandt, 1853. Adult male pleon shown for all except $L$. mandtii. Color-coding and abbreviations as in Figs 2 and 3.

crab stage, the second tergite has already divided into a single median, and paired lateral and marginal plates. On the marginal and lateral plates most of the megalopal spines still can be recognized. Marginally, tergites three and four are still distinguishable; however, decalcification is well underway centrally, with only a few chitinous patches and still calcified spines of the third still visible.

Hapalogaster (cf. McLaughlin \& Lemaitre 2001, figs. 4f-k): Development of the megalopa and first crab stage of $H$. dentata (De Haan, 1844), and of the megalopa, crab stages 1 and 2 of $H$. mertensii Brandt, 1850 , have been examined. In both species, chitinous tergites are present in both the megalopa and crab stage 1 . In crab stage 1 of $H$. mertensii the surface is provided with scattered short setae, but granules are not apparent, and just slight lat- eral thickenings can be observed in the second tergite. Only the first and sixth tergites and telson are clearly delineated in crab stage 2 . Segmentation of the primarily membranous second through fifth tergites is apparent only laterally. Very faint indications of incipient lateral and possibly marginal plates can be detected on the second tergite, and very slight lateral thickenings mark the third and fourth tergites.

Placetron (cf. McLaughlin \& Lemaitre 2001, figs. 5a-d): In P. wosnessenskii Schalfeew, 1892, the six distinct tergites are chitinous and unarmed in both the megalopa and crab stage 1. Changes from the megalopa pleon are seen in early crab stage 1 with the third through fifth tergites becoming centrally narrower, with later crab stage 1 specimens showing indications of lateral plate delineation. 
Oedignathus (cf. McLaughlin \& Lemaitre 2001, figs. 5e-i): As in Placetron, the tergites of the megalopa of $O$. inermis (Stimpson, 1860) are simply chitinous. However, in crab stage 1, while the first and second tergites are quite distinct, tergites three to five are only clearly distinguishable laterally. The first tergite is still chitinous; the second has the marginal regions noticeably thickened, and the lateral areas are faintly indicated. The tergites of the third through fifth pleomeres have become completely membranous, although each is still faintly delineated. The dorsal pleonal surface is covered with scattered, tiny, short bristles and occasional minute spinules.

\section{Results}

McLaughlin \& Lemaitre (1997) expressed the belief that decalcification and sundering were major components in lithodid pleonal plate development, and to a certain extent the above summation has shown that this is true. McLaughlin \& Lemaitre (2001) commented that while they did not have direct information on marginal plate development in $\mathrm{LO}$ pholithodes, it could be seen to a certain extent in Phyllolithodes. It also was very apparent that in Acantholithodes the marginal plates correspondingly arose from division of the existing lateral plates. Similar division of the lateral plates in Lithodes aequispinus (Fig. 3C2) and L. santolla (Fig. 4C1) has been observed at the first and/or second crab stage; however, contrary to expectations, by the third or fourth stage the marginal and lateral plates of the third through fifth tergites refuse (Figs. $3 \mathrm{C} 3$, $3 \mathrm{C} 4 ; 4 \mathrm{C} 2,4 \mathrm{C} 3$ ), and the development of supplemental marginal nodules begins (Figs. 3C4; 4C3). Clearly this peripheral development leads to the "marginal" plates seen in the adilt pleon of $L$. santolla (cf. Macpherson 1988: pl. 10, fig. B) and L. aequispinus, and these peripheral plates are not homologous with the marginal plates of the second tergites in these species.

These documented tergal transformations unequivocally refute Bouvier's (1894a, b, 1895, 1897) hypothesis of lithodid plate formation, and his concept of lithodid carcinization. However, Boas' (1880a, b, 1924) hypothesis, as it pertains to pleonal tergite development, did not require the invasion of an entirely membranous pleon by calcified nodules and their subsequent fusion. Boas thought, correctly, that the membranous condition and plate reduction seen in pagurid tergites represented decalcification. Nevertheless, the descriptions of tergite development in several lithodids by Crain \& McLaughlin (2000a, b), McLaughlin \& Lemaitre (2001), McLaughlin et al. (2001, 2003 ), and McLaughlin \& Paul (2002) negate the validity of Boas' (1924) explanation that the well calcified second tergite of Lithodes was a subsequent reinforcement of the membranous area between the two tergal plates of Pagurus. In all paguroid megalopae, the second tergite is a single, entire, commonly chitinous plate. As shown in the descriptions of megalopal and early crab stages of several Pagurus species (Carvacho 1988; McLaughlin et al. 1989, 1992, 1993; Crain \& McLaughlin 1994) and of a species of Anapagurus Henderson, 1886 (Ingle 1990), the tergite of the second pleomere begins to lose its median distinctiveness only with the molt to crab stage 1, and this through decalcification and/or dechitinization, not division. In the genera of the subfamily Lithodinae, the second tergite, if not at least partially calcified at the megalopal stage, quickly becomes so in crab stage 1 or 2 in most genera. Concurrently or subsequently, this tergite may undergo division but not decalcification. In Cryptolithodes and some genera of the Hapalogastrinae calcification of the second tergite is lacking in the first or second juveniles stages, but this condition reflects heterochronic calcification, not loss. Boas (1924), like Bouvier (1894a, b, 1895, 1897) considered that the marginal plates of the Lithodinae tergites were new additions to the original tergites. As has been shown, the marginal plates of the second tergite, when they are present, like the lateral plates, result of divisions of the original megalopal tergal plate. The marginal plates of tergites 3-5 do separate from the lateral plates in the second crab stage in Lithodes santolla and L. aequispinus and then refuse in the following stage(s). In these species, and in Paralomis granulosa, the subsequent development, in the adjacent marginal integument, of nodular areas of calcification that frequently fuse and form "accessory marginal plates" are new additions, but these are not homologous with the mar- 
ginal plates of the second tergite. The marginal plates of the third through fifth tergites seen, or indicated in Phyllolithodes and Acantholithodes (McLaughlin \& Lemaitre 2001: figs. $2 \mathrm{~g}, 4 \mathrm{~b}$ ), similarly arise from division with the lateral plates at crab stage 1 or 2 . That these refuse, as they do in Lithodes is most probable, given the adult structure of the marginal calcifications, but until additional stages are documented we can not be absolutely certain.

Having found no pleonal developmental evidence to support the prevailing doctrine of transformation of the lithodid pleon from that of a shell inhabiting pagurid, it is now necessary to examine the data available to see if it is possible to ascertain which of the two more publicized recent hypotheses, Cunningham et al.'s (1992) "from a hermit to a king" or McLaughlin \& Lemaitre's (1997) "from king to hermit" is most credible. Despite the fact that the former was based on molecular evidence and the latter on morphological evidence, both hypotheses acknowledged the close relationship between pagurids and lithodids. Cunningham et al. (1992) supplemented their DNA evidence with the shared lithodid-pagurid character of pleonal asymmetry, the presumed geological age of Pagurus as opposed to lithodids, and the purportedly comparable ontogeny of the coconut crab, Birgus latro (Linnaeus, 1758). McLaughlin and Lemaitre (1997) discussed asymmetry, with particular emphasis on pleopod and uropod asymmetries, from the stand point of adult morphology. They did not mention geologic age or address the presumed carcinization in Birgus latro. These latter two points can be clarified by perusal of the existing literature.

With regard to geologic age, suffice it to say that many of the fossil claws attributed to hermit crabs may or may not be accurately identified (AquirreUrreta \& Olivero 1992). Factual fossil shell-dwelling pagurids appear to have been reported only by Mertin (1941), Hyden \& Forest (1980) and Aquirre-Urreta \& Olivero (1992), the latter confirming the presence of a pagurid as far back as the Cretaceous. However, the claim by Cunningham et al. (1992) of the relative youth of lithodids was recently challenged by Feldmann (1998) who described a species of Paralomis from the Miocene of New Zealand. Although the Miocene is appreciably younger than the Cretaceous, Feldmann suggested that the ab- sence of lithodids in the fossil record probably was the result of the habit of most species to reside in deep water, and that the lithodid fossil record would go well beyond the Miocene when fossils were accurately recognized.

Borradaile (1916), Wolff (1961), Cunningham et al. (1992) and Morrison et al. (2002) all indicated that carcinization in Birgus latro represented a parallel evolutionary event, distinct from carcinization in the lithodids. We concur that carapace development in Birgus is distinct from that of lithodids. However, the broadening observed in the posterior carapace of $B$. latro was shown by Harms (1932) to result from changes in the animal's respiratory mechanism as an adaptation to terrestrial life, and thus really is not homologous with the broadening of the brachyuran or even lithodid carapace. Harms (1932: 263) implied that the observed shortening of the pleon of young Birgus reflected muscular contraction, as he noted that in preserved specimens, the pleon was considerably more extended. The transformation of pleonal tergites from the soft condition seen in Coenobita species to the heavily thickened, chitinous or somewhat calcified plates that protect the adult pleon of Birgus required more than two years in the specimen that Harms observed and appeared to have been environmentally triggered. Other specimens that did not abandon their shells showed no such thickenings. Although descriptions of zoeal and megalopal stages are adequate for a number of coenobitids and Birgus, juvenile stages are not. Held (1963) and Reese \& Kinzie (1968) presented interesting accounts of megalopal and early juvenile activities of $B$. latro, as did Brodie (1999) for first crab stage Coenobita compressus $\mathrm{H}$. Milne Edwards, 1837, while Harms $(1932,1938)$ supplied limited information on pleonal tergite development and asymmetry. Unfortunately none of these accounts provided adequate data to permit the inclusion of either $B$. latro or any Coenobita species in the present analysis.

The mitochondrial gene rearrangement study of Morrison et al. (2002) purportedly supported Cunningham et al.'s (1992) conclusion of hermit crab ancestry, but what Morrison et al. (2002) actually demonstrated was just parallel evolution of the crablike body form, a conclusion similarly reached by Borradaile (1916), Wolff (1961), and McLaughlin 
\& Lemaitre (1997). Genetic information is without doubt a vital tool in investigating phylogenetic relationships, but the interpretations and conclusions drawn from supplemental information must be based on equally accurate facts. For example, Morrison et al. (2002) cited Blackstone (1989) to support their theory that changes in relative size and shape could easily be generated by a heterochronic shift in developmental timing. However, Blackstone's data for 'displacement heterochrony' and the associated carcinization presumably exhibited by two populations of a species of a west coast hermit crab were subsequently shown by Crain \& McLaughlin (1994) to simply reflect morphological differences between two distinct species. Morrison et al. (2002) offered no additional evidence, other than their interpreted "support" to contradict the McLaughlin and Lemaitre (1997) hypothesis.

\section{From hermit to king, or king to hermit?}

\section{Analysis by Richter \& Scholtz}

Richter \& Scholtz (1994: 188) stated unequivocally that without a phylogenetic analysis it would be impossible to decide whether the evolution from a "hermit" to a "king" or from a "king" to a "hermit" would be more likely. Similarly, they noted that the question of polarity of evolutionary change could only be solved on the basis of a phylogenetic analysis using additional characters and with a careful and detailed comparison of the characters examined to make homology possible. Characters used by Richter $\&$ Scholtz to unite the Paguridae and Lithodidae included, but not exclusively: division of the second to fifth pleonal tergites into two lateral halves; asymmetry; fusion of the first pleonal sternite with the last thoracic sternite; fusion of some basal segments of the "outer" flagellum of the antennule; absence in most males of second pleopods; and the presence of one or more accessory teeth on the ischium of the third maxilliped. The Lithodidae were nested within the Paguridae, but considered to represent a monophyletic assemblage because adults all lack uropods and males lack pleopods 3-5.

Richter \& Scholtz [1994: 198 (2)], essentially following Boas's (1926) hypothesis, considered the division of the second through fifth tergites into two lateral plates with a loss of calcification in the midline a synapomorphy uniting the pagurids and lithodids. In terms of the adult condition, this might appear to be the case. However, in addition to demonstrating that lithodid marginal plate development in tergite 2 is not homologous with marginal plate development in tergites 3-5, we have shown that these developmental processes are considerably more complex than heretofore imagined.

Richter \& Scholtz (1994) commented that in correlation with the asymmetry of the pleon, some pleopods had been lost. They cited specifically the loss of pleopods 3-5 on one side of the pleon in males and females of "asymmetrical" hermit crabs and female lithodids But these authors indicated that the situation of the male first and second pleopods as more complex. Richter \& Scholtz (1994: 197 (3)] described the condition of paired first and second pleopods in Paguropsis typica Henderson, 1888, Paguristes barbatus Ortmann, 1892 (= Paguristes ortmanni, Miyake, 1978) and Sympagurus dimorphus (Studer, 1883) as representing the plesiomorphic state, and the ancestral state of asymmetrical hermit crabs, just as paired pleopods on pleomeres 3-5 were considered plesiomorphic. We concur that the situation presented by paired first and second pleopods in male paguroids is not just a simple matter of paired pleonal appendages. Paired first pleopods are absent in anomuran and brachyuran decapods, unless they are developed as copulatory structures. This is precisely the development seen in the examples cited by Richter \& Scholtz (1994), as well as certain other paguroids. Similarly, paired second pleopods in these particular taxa also are modified as gonopods. However, when unpaired second pleopods are present in adult male paguroids, they usually are not modified as gonopods, e.g., Diogenes, Dardanus, certain Pagurus species. Does a sexually modified pair of appendages represent a more primitive state than an unpaired and non-specialized appendage, or does loss precede specialization in the evolutionary framework? Clearly appendages arising from the second pleomere in species of one genus are positionally homologous (cf. Minelli \& Schram 1994) with those of another, but are they developmentally homologous? Our juvenile data suggest that perhaps they are not. 
Richter \& Scholtz [1994: 205 (5)] found the occurrence in lithodid female of paired first pleopods even more difficult to interpret. They suggested that the most parsimonous assumption would be that this pair of appendages represented a secondary appearance (atavism), i.e., the reappearance of a pagurid ancestral character. In referring to the paired first female pleopods as gonopods, numerous authors, including McLaughlin \& Lemaitre (1997: 114) have implied a sexual function similar to that of males for these female appendages; however, no such function ever has been documented. Pohle (1989) reported that in some lithodids, eggs were carried by these pleopods. No similar use has been recorded for other paguroids. As is pointed out in our discussion of pleopods, paired first pleopods in some female paguroids, like paired first and second pleopods in some male paguroids, do not appear to be developmentally homologous with the pleopods of the megalopa, where no first pair are ever developed. It would seem that if buds of first pleopods do occur in embryonic development as Richter \& Scholtz (1994: 206) state, their appearance in lithodids where they sometimes facilitate egg-carrying would suggest the primitive state. The absence of this function and the ultimate loss of these pleopods in many paguroid genera would then reflect the apomorphic conditions.

Contrary to Richter \& Scholtz's [1994: 198 (4)] belief, not all genera of the Paguridae have one or more accessory teeth on the ischium of the third maxilliped (de Saint Laurent-Dechancé 1966; McLaughlin, 1997). Fusion of the last thoracic and first pleonal sternites undoubtedly occurs during juvenile development, but these sternites are independent in megalopae and early juveniles (pers. obs.). Of the two other characters utilized by Richter \& Scholtz (1994), antennular article fusion can not properly be interpreted since articular segmentation is just beginning during the megalopal and early juveniles stages (Forest 1987; Carvacho 1988; McLaughlin et al. 1989, 1992; Crain \& McLaughlin 1993). Sternal fusion may occur prior to maturity, but such fusion is not apparent in early juvenile stages.

\section{Questions of asymmetry}

The handedness, as well as the pleopod and uropod asymmetries that are seen in paguroids are commonly attributed to the frequent use of many species of dextrally coiled gastropod shells. Some early carcinologists, however, suggested that asymmetry was a predetermined condition (Rathke 1842; Agassiz 1875; Thompson 1903; Boas 1926). Although all animals have been said to be asymmetrical at the molecular level (Ageno 1972; Neville 1976), symmetry is generally considered to be the primitive or plesiomorphic condition (Bouvier 1940; Scholtz \& Richter 1995; Palmer 1996). However, when symmetry is encountered among paguroids, it has been assumed to have been secondarily acquired (Bouvier 1940; Russell 1962; Elwood \& Neil 1992; Richter \& Scholtz 1994).

Asymmetry is not a phenomenon limited to paguroids. In fact, decapod asymmetry has been a subject of interest for nearly a century (Przibram 1905; Emmel 1908), but as noted by Oppenheimer (1974) interest in asymmetry has risen and fallen from time to time. Interest would again appear to be on the rise (Palmer 1994, 1996; Chippindale \& Palmer 1994; Graham et al. 1998; Klingenberg et al. 1998), and while most studies have been theoretical or broad-based, certain very important facts have been documented. Asymmetry has evolved independently many times in higher animals, and conspicuous asymmetry, according to Palmer (1996), falls into two general categories: directional asymmetry (asymmetry toward a particular side) or antisymmetry (random asymmetry). In Palmer's view, different ontogenetic origins of asymmetry imply different patterns of phylogenetic precedence; early or larval asymmetry is indicative of transition directly from symmetry to directional asymmetry, whereas "postlarval" asymmetry is indicative of a transition from symmetry to antisymmetry and ultimately to directional asymmetry. Of pertinence to our investigation is his observation of what he referred to as a nonrandom environmental trigger that might bias the late-developing asymmetries of left and right handed hermit crabs. Neither group appeared to have passed through the antisymmetry stage. However, Palmer's consideration of pagurid asymmetry was limited only to handedness, which 
he associated with propensity of many hermits to live in asymmetrical gastropod shells. Unfortunately, the complexities of paguroid asymmetries do not appear to have any straightforward answers. For example, not all hermit crabs have asymmetrical chelipeds, pleopods or uropods; some are perfectly symmetrical. In contrast, lithodids never occupy gastropod shells, nonetheless, both sexes exhibit cheliped asymmetry. However, it is only females who manifest pleonal plate and pleopod asymmetry and this is not apparent until crab stage 4 or 5 in the species that have been studied. Slight directional asymmetry is evident in the cheliped development of megalopae of some species of lithodids, whereas pleopod and uropod loss remains symmetrical. Similarly, cheliped asymmetry may be apparent in other pagurid megalopae, but it is at crab stage 1 that asymmetrical pleopod loss usually first becomes observable. In contrast, while diogenid megalopae may have asymmetrical pleopods and uropods, numerous species also have symmetrical chelipeds. Additionally, in those genera where adult asymmetry is pronounced, it most commonly is at crab stage 1 that handedness becomes apparent, as do pleopod and uropod asymmetries. However, not all of these species are asymmetrical shell dwellers. From studies on Calcinus verrillii (Rathbun, 1901), a species known to utilize both gastropod shells and polychaete worm tubes, Rodrigues et al. (2002) have suggested that it might be easier for hermit crabs to change from symmetrical to asymmetrical uropods than the reverse. Contrarily, Harvey (1998) argued that the loss of asymmetry in the uropods of Clibanarius vittatus Bosc, 1802, when deprived of spirally coiled shells, demonstrated that the constraints against symmetry were minimal. Gherardi (1996a) apparently did not observe any uropod asymmetry when normally uropod-symmetrical Discorsopagurus schmitti (Stevens, 1927) megalopae selected gastropod shells over polychaete worm tubes as habitats. The observation made by Millett T. Thompson (1903: 195) "This question of the origin of asymmetry seems to me to be insoluble at the present day." is as true now as it was a century ago. But it is most probable that no single genetic or environmental trigger is responsible.

\section{Pleopod loss and gain}

Paired first pleopods in females of most lithodid genera caused Boas (1924) to change his view of the pagurid ancestor from Pagurus to a genus like Nematopagurus or Pylopagurus. Neither of the latter genera were included in Cunningham et al.'s (1992) study, nor are they included here for lack of larval, megalopal, and early juvenile data. McLaughlin \& Lemaitre (1997) reported the presence of paired first pleopods in adult females of all Pylochelidae, the diogenid genera Paguristes Dana, 1851 and Paguropsis Henderson, 1888, and several genera of the Paguridae. No paired pleopods are present on the first pleomere in the zoeal or megalopal stages of any paguroid, although Richter \& Scholtz (1994) suggested they might be present in embryonic stages. When paired first pleopods do develop in the adult they appear to represent new structures, not modifications of existing megalopal pleopods, and they do not arise until sometime after crab stage 10 (Provenzano \& Rice 1966; Sandberg \& McLaughlin 1998; McLaughlin \& Paul 2002).

Buds, representing developing pleopods, appear, with few exceptions, in the penultimate or ultimate zoeal stages on pleomeres two to five of paguroids. These appendages, fully developed, paired, and usually biramous are characteristic of the megalopa. They are lost entirely in lithodids either with the molt to crab stage 1 or shortly thereafter, and are replaced by newly developing pleopods on the left side only in females at approximately crab stage 5 . In contrast, pleopods are reduced in the first and/ or second crab stages, and ultimately lost on one side of the pleon, in subsequent juvenile stages in the majority of pagurids. It is unclear what mechanism(s) influence pleopod loss, but loss is not uniform throughout the superfamily. For example, Provenzano \& Rice (1966) reported the reduction and ultimate loss of both second pleopods and third through fifth right pleopods in Paguristes sericeus A. Milne-Edwards, 1880 at crab stage 2. The left second pleopod remained absent through crab stage 10. Females developed an egg-bearing second pleopod on the left side of the pleon gradually in later stages, whereas males did not. In contrast, BrossiGarcia $(1987 b, 1988)$ described pleopod loss beginning at crab stage 2 in two species of another 
diogenid genus, Clibanarius Dana, 1852; but this loss involved only the pleopods of the right side. Variations were also seen in the five species of Pagurus in the present investigation. In studies of $P$. venturensis Coffin, 1957 by Crain \& McLaughlin (1993) and $P$. kennerlyi (Stimpson, 1864) by McLaughlin et al. (1989), marked reduction was found in the second pleopods on both sides at crab stage 1 and complete loss at stage 2. Similar reduction was observed for third through fifth pleopods on the right side at crab stage 1 , with complete loss in crab stage 2 . However, a tiny second pleopod bud was apparent on the left side of a presumed female of $P$. venturensis in crab stage 3, suggesting a return similar to, but more rapid than, that observed in Paguristes sericeus. Comparable second pleopod reduction in Pagurus bernhardus (Linnaeus, 1758) was reported by Carvacho (1988) and in P. ochotensis Brandt, 1851 by McLaughlin et al (1992) but without complete loss in crab stage 2 . Clearly, pleopod absence and loss, like asymmetry, lacks a single straightforward explanation.

\section{Uropod loss and transformation}

The presence of a tailfan consisting of the telson and the paired appendages of the last pleomere is considered an ancestral decapod structure (Paul et al. 1985; Paul 1989). Uropods represent a pair of larval appendages on the sixth pleomere. As has been reported by Williamson $(1974,1988)$ and confirmed for some lithodids by Crain \& McLaughlin $(2000 \mathrm{~b})$, when uropods are present they appear in the third zoeal stage, whether or not that is the ultimate zoeal stage. Williamson (1974) suggested that lack of uropod development in the higher Brachyura resulted from ancestral stock that had only two zoeal stages. In most lithodid genera where uropods are entirely lacking, the species do have only two zoeal stages. Nonetheless, uropods never develop in the lithodid genera Acantholithodes and Cryptolithodes, each having four zoeal stages (Jensen pers. comm.; Hart 1965; Kim \& Hong 2000), which certainly suggests the lack of uropod stage dependency. Uropods, when present in lithodids, are uniramous and are lost with the molt to crab stage 1 in all genera studied except Placetron (cf.
Crain \& McLaughlin 2000b). Since adults of $P$. wosnessenskii lack uropods, this is another example of heterochronic loss. In contrast, with the molt to crab stage 1 in all non-lithodids studied, the biramous megalopal uropods remain biramous but become substantially modified by the development of corneous scales on the dorsal surfaces. This development occurs whether the species is a shelldweller or not (Forest 1987; McLaughlin et al. 1989, 1992, 1993; McLaughlin 2000). Uropod asymmetry, as suggested above, may be under genetic and/ or environmental control.

\section{Polarity - or what constitutes a primitive character state?}

In their study of adult characters, McLaughlin \& Lemaitre (1997) used Neoglyphea inopinata Forest \& de Saint Laurent, 1975, as the out-group for testing the hypothesis that carcinization had occurred and that lithodids represented the advanced state. No information on development is available for $N$. inopinata, thus no parallel out-group analysis is possible.

Kluge (1985) and O'Grady (1985) both perceived ontogenetic data as providing three basic uses to phylogenetic systematics, i.e., to provide assessment of homology, to serve as an extra source of observations with which to judge historical relationships, and to serve to polarize character transformations. Although Christofferson $(1987,1988 \mathrm{a}$, b, 1989) and $\mathrm{Ng} \&$ Clark (2000) used both larval ! and adult characters in assessing phylogenetic relationships of the Eucarida, Caridea, and certain Brachyura, as pointed out by Hickman (1999), the exclusive use of invertebrate larval data in cladistic analyses is in its infancy. Only a few recent larval decapod studies have applied phylogenetic methods (Clark \& Webber 1991; Marques \& Pohle 1995, 1998). Polarity was determined by Clark \& Webber (1991) and Marques \& Pohle (1995) using the assumption that evolution had proceeded by oligomerization, i.e., the loss and reduction of segments and setation elements. However, Marques \& Pohle (1998), using out-group analysis, tested the applicability of the oligomerization method of polarity determination, and found it unjustified in that it 
did not provide the most parsimonious explanation of the data set. In contrast, they believed their results demonstrated that only the use of out-group comparison to polarize character transformations would produce the most parsimonious hypotheses while allowing the researcher to recognize possible addition events. However, it should be noted that Koenemann \& Schram (2002) now argue that maximum parsimony is a biased method to analysze development sequence data.

Marques \& Pohle's (1998) results not withstanding, and the out-group method's common usage in assessing polarity in adult phylogenetic investigations (Meier, 1997), some researchers consider that the out-group method has disadvantages when applied to ontogenetic sequences (Nelson, 1978, 1985). For example, the out-group method of determining polarity assumes a knowledge of higher relationships (Nelson 1973a, b, 1978), and also is concerned, not so much with character polarity, but with connotations of ancestry (Williams et al. 1990). The selection of one or more taxa as out-groups theoretically establishes a hypothetical ancestor with all primitive characters, and character-state distributions are summarized at the out-group node (Maddison et al. 1984; Bryant 1997). Since our concern is for attributes pointing to possible carcinization events, our application of cladistic methods is once again somewhat unconventional (cf. McLaughlin \& Lemaitre 1997: 96), thus determination of ancestry is not our specific aim.

An alternative to the out-group method is the ontogenetic polarity criterion, or Nelson's Rule (Nelson, 1978). As elucidated by Bryant (1997), the distribution of character states through the ontogenies of members of the ingroup is used to infer the expected character states at the ingroup node. Specifically, Nelson's criterion considers that the transformation of an ontogenetic character observed to be more general to one observed to be less general, represents a transformation from primitive to advanced. Nelson, however, did not interpret general and common as equivalents, as some of his subsequent critics have (Kluge \& Strauss 1985; Kluge 1988; Kraus 1988). Patterson (1994, 1996) paraphrased Nelson's (1978) criterion as “absence is more general than presence". Unfortunately, generality is often in the eye of the beholder, and can be interpreted quite differently by different investigators (e.g., Mabee 1989, 1996; Patterson 1996). Similarly, absence does not universally precede presence (e.g., Fong et al. 1995).

In the opinion of de Queiroz (1985) "... characters do not transform in ontogeny; ontogenetic transformations are themselves the characters." Importantly, Wheeler (1990) has made a justifiable distinction between character adjacency and character polarity. In an ontogenetic sequence, transformations in character states can be observed (character state adjacency), but such transformations do not provide information about polarity per se. Tests on the outgroup criterion and "Nelson's Rule" (Wheeler 1990; Meier 1997) have shown that both methods give approximately equally parsimonious results. Bryant (1992), in comparing the two methods, indicated that both require monophyly of the study group and comparison of equivälent sets of ontogenetic stages. Additionally, according to Bryant, the use of outgroup analysis necessitates monophyly of a more inclusive group, or close relationship between the study group and particular out-groups, as well as an adequate survey of the distribution of character states among out-groups. Contrarily, Nelson's Rule, as interpreted by Bryant, requires the retention of plesiomorphic states in the ontogenies of descendants. In the present study of megalopal and early juvenile development, available evidence suggests that all of the above criteria for the application of Nelson's Rule have been met. However, as pointed out by Christofferson (1995), ontogenetic polarities of instantaneous characters, because of heterochrony, do not necessarily coincide with phylogenetic polarities of ontogeny. From our data, we have definitive evidence on character state adjacency. By applying Nelson's Rule, we have, for some characters, been able to postulate polarities. However, in other character transformations, this method of polarity determination does not seem applicable. For example, there is no ontogenetic evidence to suggest that certain losses and/or transformations occur in ordered, stepwise manners among taxa. Specifically in coding pleopod reduction or loss and uropod loss or transformation, we have used the "intermediate method" of Wilkinson (1992, 1995), which hypothesizes that if a character state is intermediate in form, size or number between 
two other character states it is considered phylogenetically intermediate between those two other states. The rationales that have gone into our decision-making processes are presented for the characters used in our analyses.

\section{Semaphoronts}

The term semaphoront has been interpreted differently by various authors (Hennig 1966; Brooks \& Wiley 1985; de Queiroz 1985; Nelson 1985; O'Grady 1985; Wheeler 1990). Our use of the term, like our application of cladistic analysis is perhaps unconventional. We use semaphoront to indicate an assemblage of individuals of a monophyletic group at an identifiable and comparable period in their life cycles. In the present investigation we have examined two semaphoronts, megalopal/juvenile and larval. The former semaphoront includes all paguroid species for which data on particular aspects of megalopal/juvenile morphology (megalopa, crab stage 1 , and crab stage 2) are available.

Marques \& Pohle (1998) stressed the need for developmental homology, emphasizing that if a phylogenetic hypothesis is based on non-homological semaphoronts, that hypothesis will likely be wrong. Having found no evidence to the contrary, we have followed Hennig's (1966) auxiliary principle and assumed [developmental] stage homology in a "postlarval" (megalopa/juvenile) semaphoront. Regrettably, data are not complete for all stages beyond crab stage 1. Maddison (1993) and Hawkins et al. (1997) have reviewed the problems arising from missing data, versus missing characters and pointed out some of the erroneous results that can occur when computerized analyses encounter missing information. Consequently, we have limited our data to taxa experimentally observed, reported in the reliable literature and/or, where character adjacency has permitted, extrapolations. However, given the reversals observed in lateral and marginal plate divisions in Lithodes at crab stage 3, we have not pursued formal cladistic analyses beyond crab stage 2. This stage limitation notwithstanding, we have utilized the data from crab stage 3 and beyond in drawing our ultimate conclusions.

Confirmable reports of direct development in the
Paguroidea by Barnard (1950), Dechancé (1963), and Morgan (1987) have described hatchings at the megalopal stage (pre-imago); in all other studies one or more zoeal (larval stages) also are involved. In our analyses, the megalopa is considered the basal point of the "postlarval" semaphoront whether abbreviated development is considered advanced (cf. Rabalais \& Gore 1985) or primitive (Wolpert 1990, 1994). Among members of our "postlarval" semaphoront, the occurrence (insertion) of the megalopal stage (pre-imago) is universal.

Our larval semaphoront was to have included those paguroid species for which pertinent zoeal data could be paired with megalopal/juvenile information, at least at the generic level. However, we encountered two major problems. The first dealt with character selections. Phylogenetic brachyuran larval studies most frequently have placed considerable emphasis on setal differences in primary zoeal feeding appendages (Clark \& Webber 1991; Marques \& Pohle 1995, 1998; Clark 2000; Ng \& Clark 2000). Unfortunately in paguroids, these appendages, i.e., paired mandibles, maxillules, and maxillae, may be well developed or rudimentary, depending upon whether or not the larval and/or megalopal stages are lecithotrophic (Van Dover 1982; McLaughlin et al. 2001, 2003). In the zoeal studies considered in our review, all paguroid species had type 1 (cf. Van Dover et al. 1982) maxillary scaphognathites in zoeal stage 1 and followed those authors' type A sequence through subsequent stages; however, setation was noticeably reduced in species known to be at least facultatively lecithotrophic.

Lecithotrophy has not been seriously investigated in paguroids. However, Anger (1989) and Harvey (1996) have reported the occurrence of 'secondary lecithotrophy' in the megalopal stage of several Pagurus species and Harvey has indicated that both zoeal and megalopal stages of Paguristes tortugae Schmitt, 1933 are lecithotrophic. Anger (1996) and McLaughlin et al. $(2001,2003)$ have recorded similar lecithotrophy in species of Lithodes and Paralomis. To avoid the introduction of seemingly morphological differences that may in fact be differences in developmental patterns (cf. Chai 1974), feeding appendages had to be omitted from our consideration. 
The second problem dealt with ontogenetic stage homology, a matter of critical concern in phylogenetic analyses. In the Paguroidea, although the most common number of zoeal stages is four, that number does vary among and within genera, and occasionally even within species. Such variation in some taxa simply reflects environmental influences (Cabrera Jiménez 1966; Lang \& Young 1977; Brossi-Garcia \& Hebling 1983; Siddiqui et al. 1991), while in others these variation actually are deletions [elimination of a stage ] (Gore 1985; Clark 2000) (or insertions; cf. Wolpert 1994). Marques \& Pohle (1998), when confronted with variations in the number of zoeal stages in their study groups, were able to demonstrate that the second stage of their ingroup was homologous with the second stages of the out-groups despite variation in the total number of stages. Clark (2000) however, considered specific morphological attributes as characters across a series of stages with polarity conferred by the timing of their appearances. Specifically, a given character in all taxa presumably was homologous across all stages; its polarity was considered derived if it appeared earlier in the sequence of zoeal stages than the same character in the out-group. This reasoning requires that stages also are ontogenetically homologous among all taxa. Perhaps this is a reasonable expectation in some brachyuran groups; however it is certainly not the case in paguroids.

For example, a review of paguroid larval characters has shown that while some of the variations observed appear to be simply terminal deletions or insertions, e.g., four rather than five zoeal stages or vise versa, some more importantly would seem to be initial deletions (stage 1, or elements of it, eliminated or passed through prior to hatching). Initial deletion means that the state of a character in species hatching in a more 'advanced' condition will not be developmentally homologous with that same character in a species without advanced hatching. In one of the more readily recognizable scenarios, the first decapod zoeal stage (ZI) (prezoeas excluded) is defined as having sessile eyes regardless of the number of zoeal stages (Gurney, 1942: 123). However, in Lopholithodes (cf. Crain \& McLaughlin 2000a), Lithodes (cf. McLaughlin et al. 2001), Paralomis (cf. McLaughlin et al. 2003), Anapagurus (cf. Ingle 1990), and Pylocheles mor- tensenii (cf. Saito \& Konishi 2002), the eyes at hatching are stalked or at least only partially fused to the orbital wall. In Lithodes only three zoeal stages precede the metamorphic molt, suggesting perhaps that the first stage has been deleted. In Paralomis where the molt to megalopa is preceded by only two zoeal stages, it would appear as though at least one or perhaps even two zoeal stages have been deleted. In contrast, in the diogenid genus Paguristes, where two or three zoeal stages also are reported (Hart 1937; Rice \& Provenzano 1965; Provenzano 1978), ZI eyes are sessile, suggesting that perhaps stage deletions in this genus are terminal. Alternatively, Ingle (1990) for the pagurid, Anapagurus chiroacanthus (Lilljeborg, 1855), and Crain \& McLaughlin (2000a) for the lithodid, Lopholithodes mandtii, reported stalked or at least only partially fused eyes in ZI; both taxa have four zoeal stages, the number-most common for species of Pagurus, which have sessile eyes at hatching. Do differences in ocular development among species of Paguristes and Pagurus, with two or three and four zoeal stages, respectively, but sessile eyes initially, reflect the primitive condition, while species of Anapagurus and Lopholithodes, each also with four zoeal stages but stalked eyes, reflect the derived condition in equivalent stage ZI larvae? If so, is this derived state ontogenetically homologous with the "derived" states seen in "ZI" Lithodes and "ZI" Paralomis with only three and two zoeal stages, respectively? We have found no evidence to allow us to assume that this is true. The condition of the eyes at hatching is just one of a number of stage-variable characters of this complexity that cast critical doubt on developmental stage homologies or equivalent sets of ontogenetic stages among paguroids. Without these, meaningful phylogenetic analysis cannot be expected. Consequently, we have not cladistically evaluated our larval phase data.

\section{Megalopa/early juvenile characters and character states.}

We have followed the recommendation of Wiens (2001) to explicitly document our character choices. Table 1 provides a summary of the characters and character states for the "postlarval" (megalopa/juve- 
Table 1. Characters for carcinization analysis. Megalopa, Crab stage 1 and Crab stage 2 treated individually (first 16 taxa, Table 2) or Megalopa and Crab stage 1 treated individually (all 25 taxa, Table 2). Paragraph numerals correspond to attributes discussed in text (see Megalopa and juvenile characters and character states). Character state symbols are in parentheses, 0 indicating plesiomorphy.

1. Carapace.

1a. Calcification: distinctly calcified (0); partially calcified (1); chitinous (2)

1b. Carapace delimitation: shield not delineated (0); shield delineated (1)

1c. Rostrum: well developed (0); reduced (1); lost (2)

2. Ocular peduncles and acicles: acicle development: no plate development (0); simple plate developed (1); plate with acicular spine(s) or projection (2)

3. Thoracic appendages:

3a. Fourth pereiopods: developed as walking legs (0); reduced, modified (1)

3b. Fifth pereiopod: setae only (0); setae plus very few corneous scales (1); numerous corneous scales (2)

4. Pleonal carriage: straight and extended (0); twisted and extended (1); straight but somewhat flexed (2); straight but flexed and held closely against cephalothorax (3)

5. Pleonal tergite 1:

5a. Tergal calcification: calcified (0); chitinous to weakly calcified (1) entirely chitinous (2); membranous (3)

5b. Tergal distinctness: tergite distinct $(0)$; tergite identifiable but fused with tergite $2(1)$; tergite weakly identifiable (2); tergal identity lost (3)

6. Pleonal tergite 2:

6a. Calcification: calcified (0); chitinous to weakly calcified (1) entirely chitinous (2); membranous centrally (3); entirely membranous (4)

6b. Division: undivided (0); marginal plates slightly to clearly delineated (1): lateral plates slightly to clearly delineated (2); marginal and lateral plates slightly to clearly delineated (3)

6c. Tergal identity: distinct (0); partially obscured or lost (1); completely lost or nearly so (2)

7. Pleonal tergite 3:

7a. Calcification: calcified (0); chitinous to weakly calcified (1) chitinous (2); partially membranous (3); entirely membranous (4)

7b. Division: undivided (0); marginal plates slightly to clearly delineated (1): lateral plates slightly to clearly delineated (2); accessory lateral plates delineated (3); marginal and lateral plates delineated (4); lateral and marginal plates refusing (5)

7c. Tergal identity: distinct (0); partially obscured or lost (1); completely lost or nearly so (2)

8. Pleonal tergite 4:

8a. Calcification: calcified (0); chitinous to weakly calcified (1) entirely chitinous (2); partially membranous (3); entirely membranous (4)

8b. Division: undivided (0); marginal plates slightly or clearly delineated (1): lateral plates slightly or clearly delineated (2); accessory lateral plates delineated (3); marginal and lateral plates delineated (4); marginal and lateral plates refusing (5)

8c. Tergal identity: distinct (0); partially obscured or lost (1); completely lost or nearly so (2)

9. Pleonal tergile 5:

9a. Calcification: calcified (0); chitinous to weakly calcified (1) entirely chitinous (2); partially membranous (3); entirely membranous (4)

9b. Division: undivided (0); marginal plates slightly or delineated (1): lateral plates slightly or clearly delineated (2); accessory lateral plates delineated (3); marginal and lateral plates delineated (4); marginal and lateral plates refusing (5)

9c. Tergal identity: distinct (0); partially obscured or lost (1); completely lost or nearly so (2)

10. Telson:

10a. Shape: roundly subrectangular or subquadrate (0); semisubcircular to subtriangular (1); subquadrate to subrectangular but with lateral incisions (2)

10b. Armature: terminal margin unarmed (0); terminal margin with spines or spinules (1).

11. Pleopods: paired, biramous pleopods on pleomeres 2-5 or 2-4 (0); gradual loss of all pleopods on one side of pleon (1); gradual, but complete loss of pleopods of pleomere 2, gradual loss of pleopods 3-5 on one side of pleon (2); gradual loss of pleopods on both sides of the pleon (3); loss of all pleopods (4)

12. Uropods: biramous, equal, with setae only (0); biramous, equal, with corneous scales on one or both rami (1); biramous, unequal, with corneous scales on one or both rami (2); uniramous (3); absent (4)

13. Symmetry: chelipeds equal (0); right larger (1); left larger (2)

14. Zoeal stages: $5(0), 4(1), 3$ (2), 2 (3), 1 (4) 
nile) semaphoront. Since data for crab stage 2 are more restricted, we have conducted our analysis at two levels, i.e., those taxa for which complete data are available for the three 'postlarval stages, and those taxa where data are available only for the first two postlarval stages. Table 2 furnishes the list of paguroid taxa examined and the respective character states for megalopa, crab stage 1 and crab stage 2 .

\section{Carapace.}

Although much emphasis has been put on the transition to (or from) a crab-like pleon, the carapace of a shell dwelling hermit crab and the carapace of a well calcified, crab-like lithodid similarly represent a transformation from one condition to another. Additionally, the rostrum, common to the majority of decapod zoeae, persists at least through the megalopal stage (Williamson 1982), but undergoes major reduction in juvenile stages of many paguroids. We consider three characters in the category, carapace.

1a. - Calcification. Scholtz \& Richter (1995) reported a strongly calcified exoskeleton for most adult reptant decapods, except for "asymmetrical hermit crabs" and some thalassinids, although they considered a soft cuticle as exhibited by "natant" decapods the "original" condition. While a calcified megalopal carapace is present in some lithodids, that is not true for all, nor is it true for most pagurids. In the subsequent juvenile stages, some degree of calcification may be gained, but if a calcified integument is initially present it is not lost, it is simply strengthened. Of itself, this restricted evidence would suggest that a chitinous cephalothoracic integument is the plesiomorphic condition. With any decapod, the postmolt exoskeleton is initially uncalcified (Greenaway 1985). However, this cannot be viewed as indicating an evolutionary precursory condition. The onset of calcification of the carapace varies, but clearly calcification is not an orderly and progressive transformation. We have interpreted an initially calcified carapace as primitive because of the comparable corresponding states of pleonal calcification (see rationale for characters 5-9).

1b. - Carapace delimitation. With relatively few exceptions, the pagurid megalopal carapace consists of a well-defined, chitinous shield and membranous posterior portion. In contrast, among lithodids there seems to be variation in the extent to which the anterior carapace is delimited, but a specific shield is not similarly identifiable in lithodids. Applying Nelson's Rule, the more general condition would be lack of specific delineation.

1c. - Rostrum. Rostral processes are generally well, or at least better, developed in the megalopa in all families, but show gradual or substantial reduction in subsequent stages. We consider the more general, thus primitive condition, to be a well-developed rostrum.

\section{Ocular acicles}

The interpretation of what constitutes an ocular acicle varies among authors, although all concur that its presence is apomorphic. Jackson's (1913: 40) definition as a spearhead shaped "squama", or Makarov's (1938: 126, 1962: 120) "as a small appendage ... which is usually oval with a pointed tip" has been interpreted to mean the entire calcified plate of the penultimate segment (cf. Powar, 1969) of the peduncle, as implied by McLaughlin (1974, 1983) and Martin \& Abele (1986), and has been specifically defined as such by Sandberg \& McLaughlin (1998) and Forest et al. (2000). In contrast, Richter \& Scholtz (1994: Figs. 3A, B) and Boyko \& Harvey (1999: 383, fig. 2A) have restricted the ocular acicle to the "spinose or platelike anterodorsal extensions." The calcified plate often present on the second (penultimate peduncular segment), with or without projections, is understood here as representing the ocular acicle.

\section{Thoracic appendages}

Only two pairs of thoracic appendages are considered in our analysis, as these are the only ones that appear to be correlated with carcinization.

3a. Development of the fourth pereiopod is of primary importance. The more general condition, seen in lithodids, i.e., development of the fourth pereiopod as a walking leg, is considered primitive, rather than an atavism as claimed by Boas (1924), or gene replication of the third pereiopod as suggested by Richter \& Scholtz (1994).

$3 \mathrm{~b}$. The reduction of the fifth pereiopod, although apomorphic when evaluated among all decapods, 
is a character shared by all Paguroidea. As indicated by Pohle (1989), Richter \& Scholtz (1994), and Scholtz \& Richter (1995) this appendage in the adult is specially adapted for different functions among members of the superfamily. The more general usage of this appendage is as a gill cleaner, and as such is provided only with setae. We consider setae only as the primitive condition.

\section{Pleon carriage.}

The megalopal pleon is carried, at least initially, in a straight and fully extended position in all paguroids studied. While it may remain straight or become twisted in subsequent crab stages, it may also be flexed under the cephalothorax and held closely against the cephalothorax. We consider the extended, straight pleon more general, and therefore to represent the plesiomorphic condition.

\section{5 -9. Pleonal tergites.}

Integumental calcification of the tergites, like calcification of the carapace, is not easily polarized, although Goffinet \& Jeuniaux (1994) considered decalcification of the pleon a secondary loss in paguroids. Fully calcified megalopal tergites are present in some, but not all lithodids, nor are they present in most pagurids. Following Nelson's Rule, lack of calcification should, being more general or absent, be adjudged the plesiomorphic state. However, character state adjacency demonstrates that calcification, if initially present in megalopal tergites, may be lost, whereas if calcification is not present initially in those tergites, but is subsequently gained, it is not then again lost. Consequently we consider initial calcification of the megalopal tergites the primitive state. Nevertheless, fusion and calcification in each tergite, as well as tergal subdivisions must be considered as characters distinct for each of the first five tergites. Based on the limited data available, the megalopal/juvenile sixth tergite does not provide any significant ontogenetic information.

5. - Tergite 1. Only two characters are applicable to this tergite, calcification and tergal identity. Presence of a calcified tergite is considered plesiomorphic, as is the retention of tergal identity .
6. - Tergite 2. Three characters are needed to evaluate the changes that occur in this tergite: 1) calcification, 2) division, and 3) loss of identity. Character states for tergal division are undivided, marginal plates delineated, lateral plates delineated, and marginal and lateral plates delineated; for tergal identity: distinct, partially lost or obscured, and identity completely lost or nearly so. The primitive states are calcified (for the reason stated above), undivided, and distinct, the latter two being the universal megalopal conditions.

7-9. - Tergites 3-5. In addition to the characters of the second tergite, one additional character is needed, i.e., development of accessory marginal nodules. Lack of development of such nodules is considered the plesiomorphic condition.

\section{Telson}

Differences in telson shape and armature are observable in early juveniles. The typical, roundly subrectangular or subquadrate, and unarmed telsons of the megalopae are judged to be plesiomorphic.

\section{Pleopods}

After reviewing these losses in early juvenile stages among diogenids, pagurids, parapagurids and lithodids, it has become clear that the majority of species undergo a more or less gradual loss. We have, therefore, coded the complete loss and various degrees of gradual pleopod loss numerically using Wilkinson's $(1992,1995)$ ranking methods, but these representations are not meant to suggest an ordered transition.

\section{Uropods}

With the molt to megalopa, uropods, if initially present in lithodids, are quickly lost, while uropods in other paguroids are dramatically altered. Here again we have used Wilkinson's $(1992,1995)$ method to code the character states, but not to suggest an ordered transformation.

\section{Symmetry}

We will consider only cheliped asymmetry here, as it is the only element not incorporated into other characters. Megalopal symmetry is adjudged primitive, however coding of right and left handedness is not an indication of presumed polarity. 


\section{Zoeal stages.}

We have included the number of zoeal stages passed through by each taxon, whether these might be considered to have preceded the megalopa or been inserted following it because there undoubtedly is informational value in the extent of larval influence.

\section{Cladistic analyses}

Cladistical analysis was performed only on the data of our "postlarval" semaphoront of the Paguroidea. These data were analyzed using PAUP version 4.0 beta 11 (Swofford, 2002), utilizing data matrices (Table 2) created in MacClade verrsion 3 (Maddison $\&$ Maddison, 1992). Cladograms (Figs. 6, 7) were generated using the Branch-and-bound search option with the following parameters: addition sequence, furthest; branches collapsed if maximum branch length is zero; initial upper bound computed via stepwise; "Multrees" in effect; topological constraints not enforced; midpoint rooting in effect; and all characters unordered and with equal weight (1). In interpreting these cladograms, however, it must be emphasized that for reasons previously explained, the analyses was done without the use of an out-group (unrooted), so no ancestry can be identified. Unrooted trees such as these can only indicate relationships and not order of descent (Swofford et al., 1996; Hall, 2001). And while we refer to the positional alignment of taxa as sister groups, we do not intend to suggest phylogenetic relationships. As may be seen from the discussion below, we have, for the most part, relied upon character adjacencies and have followed character transformations in our determinations of directional change. Despite our unconventional use of cladistic analyses and the limited postlarval data base, the trees generated (Figs. 6,7 ) have shown certain points quite clearly. The first, and unquestionably the most significant is the distinct separation of lithodids from species of Pagurus. This separation is in marked contrast to the results presented by Cunningham et al. (1992: 539, fig. 1) who interpreted their DNA and other data to suggest that Lithodes aequispinus (as L. aequispina) and Paralithodes camtschaticus were nested within the genus Pagurus. As may be seen in Fig. 6, the less calcified Hapalogaster is the sister group to the more heavily calcified genera Lopholithodes, Paralomis and Lithodes, while apparent links between the lithodids and Paguristes and Discorsopagurus are unresolved. The former is a shell-inhabiting genus, the latter a polychaete worm tube dweller. However, these results cannot be interpreted as indicative of true, albeit distant, genetic relationships, but simply as the closest taxa that could be determined by a very small database. Among species of Pagurus, the sister taxa relationship between Pagurus bernhardus and P. ochotensis is to be expected; as adults they are both included in the bernhardus group of McLaughlin (1974). The less resolved relationships of the remaining Pagurus species reflects the polyphyly recognized within this genus. Although the cladogram does give some suggestion of relationships, it is not possible from it alone to determine whether evolution has proceeded toward or. away from Pagurus.

The tree generated for only the megalopal and first crab stages (Fig. 7) is even less informative, but the distinct separation of the lithodids from the other paguroids is clearly maintained. Intrageneric similarities in developmental patterns are supported by the nesting of the species of Paralithodes and Cryptolithodes, whereas the nesting of Acantholithodes hispidus and Oedignathus inermis is most probably attributable to the onset of decalcification or dechitinization at crab stage 1 in both taxa. Data from additional early juvenile stages would undoubtedly result in distinct separation, as is already apparent in Phyllolithodes papillosus. The unresolved branches for Placetron wosnessenskii and the two species of Hapalogaster can most probably be attributed to the slower rates of pleonal transformation in the early postlarval stages of these taxa. Though unresolved, a suggested link between the Lithodidae and the remaining paguroids through Porcellanopagurus filholi Filhol, 1885b, may reflect a real pathway, or simply an independent "carcinization" event. Species of Porcellanopagurus share with all lithodids the complete absence of male pleopods, and with the Hapalogastrinae a reduced pleon.

A comparison of data from the megalopal and first crab stage as opposed to that from the megalopa and two early crab stages indicates that the reduc- 


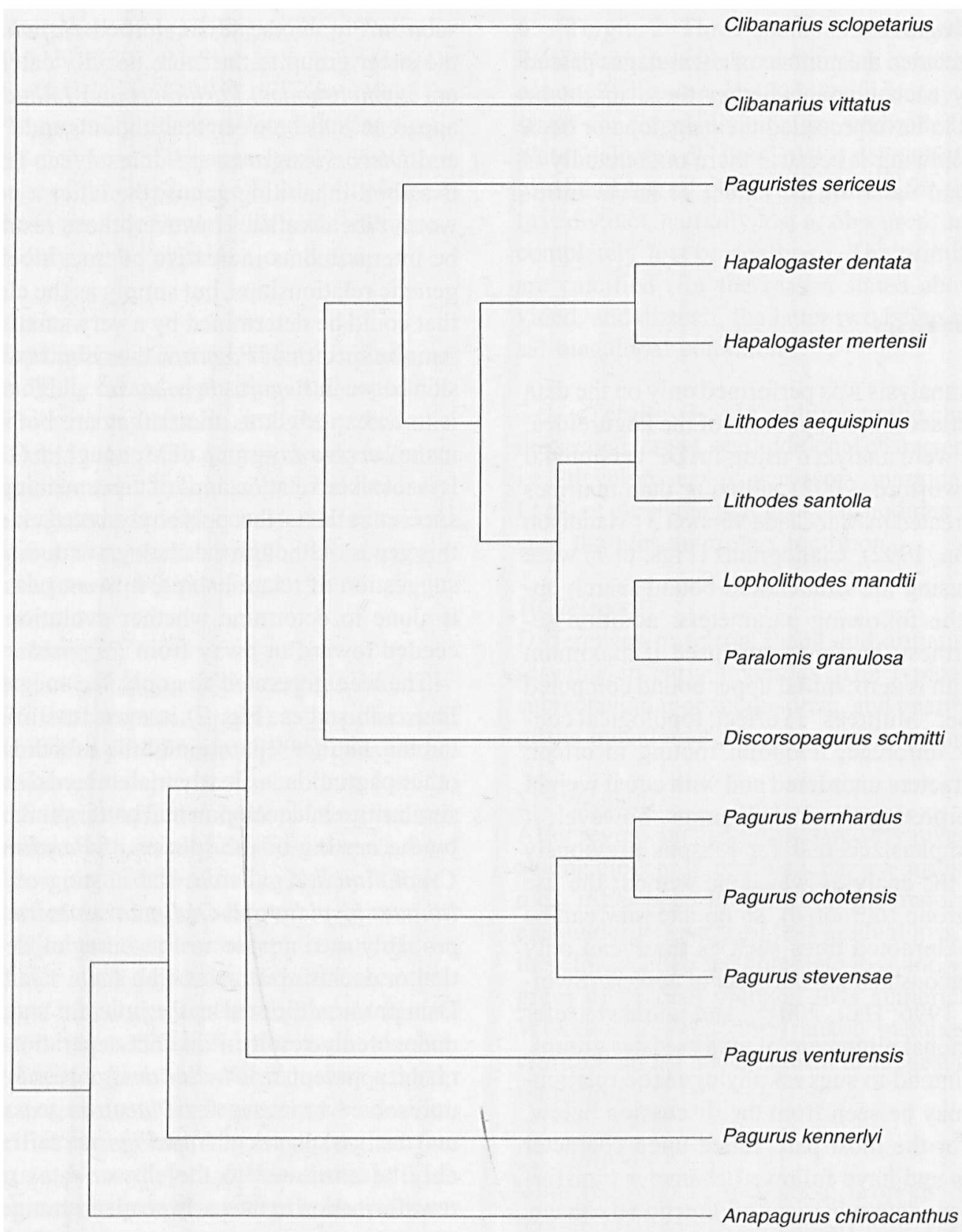

Fig. 6. Cladogram of strict consensus tree of three equally parsimonious trees (length $=158$ steps) obtained from analysis of "postlarval" semaphoront (megalopa, crab 1, and crab 2) of 16 taxa using 75 characters. Rohlf's consistency index $=0.863$. Clades are supported by $100 \%$ of trees.

tion in taxa had little appreciable effect on the general pattern of relationship between lithodids and other paguroids. However, among the lithodids, the more general relationships suggested from information provided by just the first crab stage changed appreciably when two stages were considered. When only megalopa and first crab stage data were available, intergeneric relationships were rather poorly resolved. This is not surprising, as the effect of inherent heterochrony in pleonal plate development in particular, is reflected in the larger sample size. There was only a single deletion from the other 


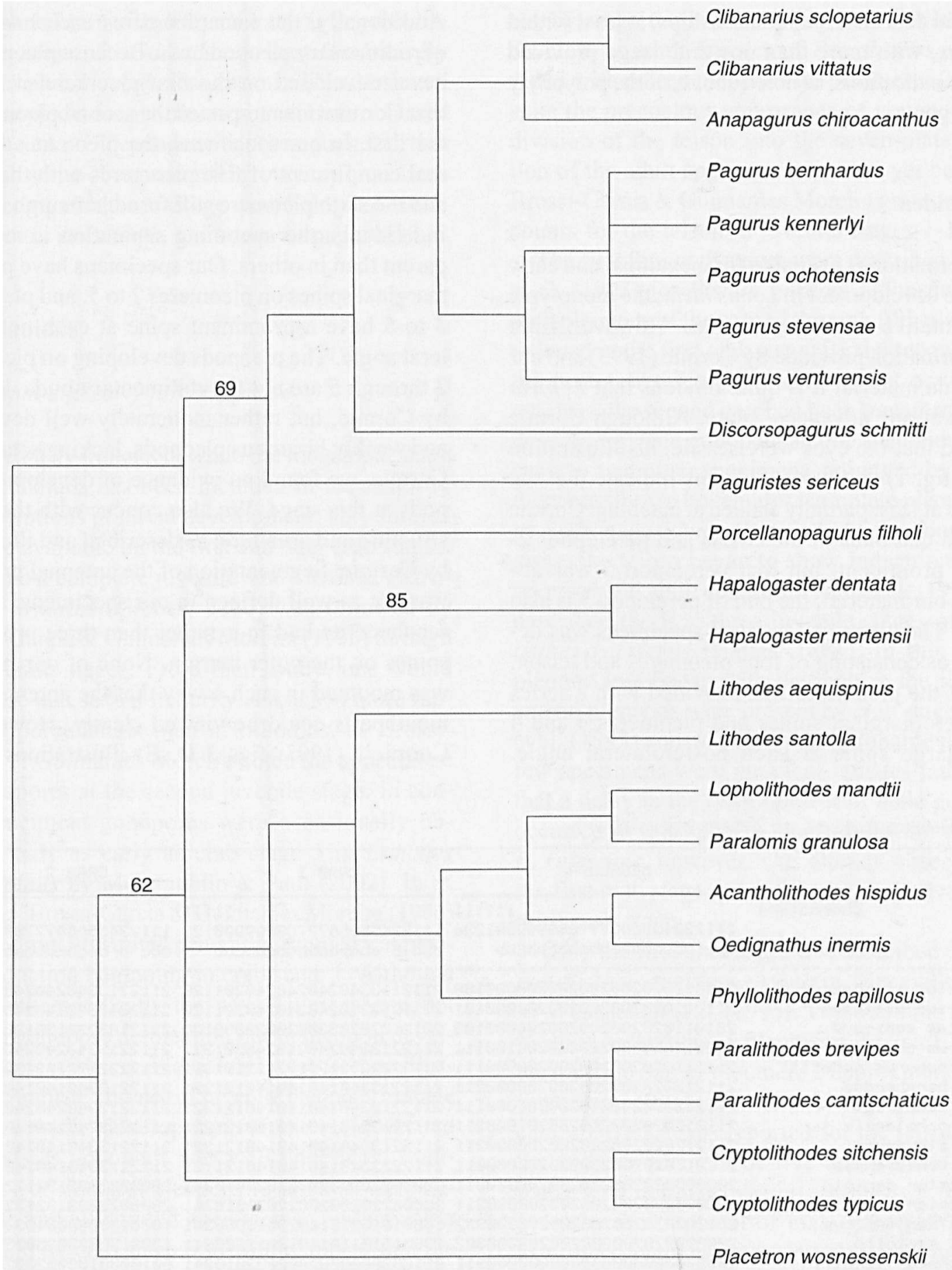

Fig. 7. Cladogram of $50 \%$ majority-rule consensus tree of 52 equally parsimonious trees (length $=132$ steps) obtained from analysis of "postlarval" semaphoront (megalopa, and crab 1) of 25 taxa using 52 characters. Rohlf's consistency index $=0.881$. Clades are supported by $100 \%$ of trees except where indicated. 
paguroid data base, yet relationships, at least within Pagurus, with more than one crab stage provided definite indications, as noted above, of the polyphyly of this genus.

\section{Lomisoidea}

No information is available for megalopal and early juvenile development in Lomis hirta, the monotypic representative of the Lomisoidea. However, from the information provided by Cormie (1993) and our own slide material it is quite obvious that $L$. hirta hatches at an "advanced" state. Although Cormie reported that the eyes were sessile, his illustration (1993: fig. 1) and our specimens indicate that the eyes are at least partially stalked at hatching. Cormie reported that buds of the chelas and pereiopods 2 4 were prominent, but that pereiopod 5 was absent. In our material, the bud of pereiopod 5 is also visible. The pleon of Cormie's specimens was described as consisting of four pleomeres and telson. Each of the pleomeres was provided with a series of posteromarginal spines and pleomeres 3 and 4 had a large spine at each posterolateral angle.
Additionally, the four pleomeres each had a pair of rudimentary pleopod buds. Because pleopods are never developed on the first pleomere, it is clear that Cormie misinterpreted the second pleomere for the first. In our specimens, the pleon has the normal compliment of five pleomeres with the telson and the sixth pleomere still fused, although in some individuals, the upcoming separation is more apparent than in others. Our specimens have posteromarginal spines on pleomeres 2 to 5 , and pleomeres 3 to 5 have a prominent spine at each posterolateral angle. The pleopods developing on pleomeres 2 through 5 are not the rudimentary buds depicted by Cormie, but rather moderately well developed and weakly biramous pleopods, lacking setae. Like Cormie, we found no evidence of developing uropods at this stage. We also concur with the telson structure and armature, as described and illustrated by Cormie. Segmentation of the antennal protopod was not as well defined in our specimens, and the scaphocerite had four rather than three prominent spines on the outer margin. None of our material was mounted in such a way that the antennules or mouthparts could be viewed clearly. However, if Cormie's (1993: figs 3 D, E) illustrations of the

Table 2. Data matrix $(?=$ Crab 2 characters unknown).

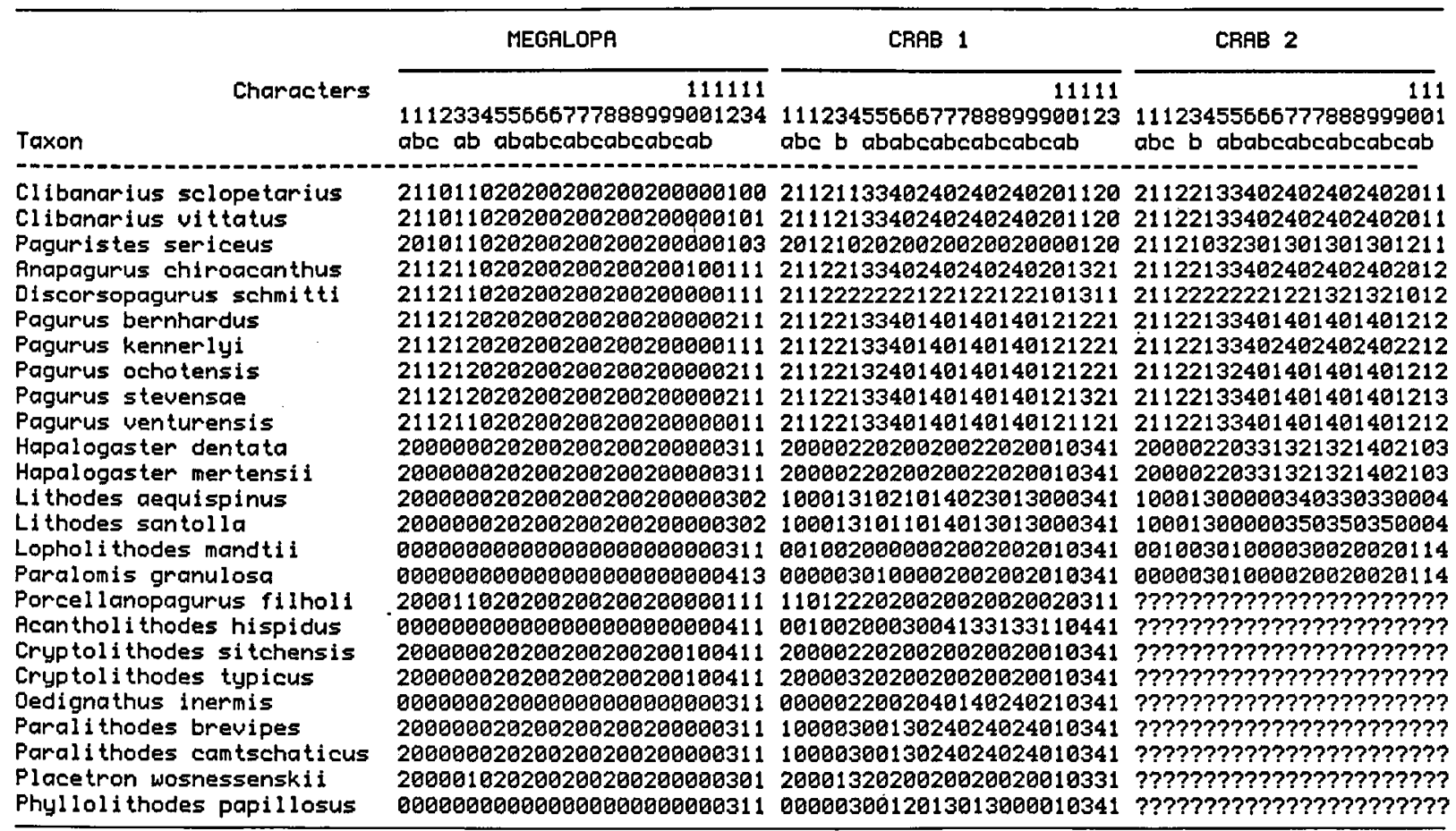


maxillule and maxilla are accurate, it is probable that the zoeae of L. hirta are at least facultatively lecithotrophic. Nevertheless, the mandible illustrated is very atypical for anomuran zoeae. Data obtained from the two independent sources suggests that although some observational errors may have been made, comparable intrastage morphological variation occurs in L. hirta, as it does in paguroids.

\section{Porcellanidae}

\section{Megalopal and early juvenile phase}

As previously indicated, while the megalopal stage in porcellanids has been included in the majority of descriptions of larval development, very limited data are available on the first and later crab stages. In the most complete juvenile study to date, Petrolisthes armatus (Gibbes, 1850) was followed by Brossi-Garcia \& Guimarães Moreira (1996) through 12 juvenile stages. From their study, one would conclude that sexual maturity is reached more rapidly in porcellanids than in lithodids, as BrossiGarcia \& Guimarães Moreira noted the appearance of gonopores at the second juvenile stage. In contrast, incipient gonopores were occasionally observed only as early as crab stage 5 in Lithodes aequispinus by McLaughlin \& Paul (2002). In P. armatus, Brossi-Garcia \& Guimarães Moreira (1996) reported and illustrated generally symmetrical pleopod reduction beginning in crab stage 1. Although these authors indicated that sexual dimorphism, not only in gonopore delineation but in pleopod development, was observable in crab stage 2 , they illustrated complete absence of juvenile pleopods in stage 3 males while development of the male second pleopods as gonopods was well underway. Rudimentary or vestigial pleopods in females were described and illustrated for stage 3 , with further reduction by crab stage 6 . It would appear that the authors did not differentiate whether these rudiments were remnants of early juvenile pleonal appendages or actually buds of newly developing female pleopods. However, the illustrated absence of the fourth pleopods in stage 3 and their reappearance at stage 6 would suggest that females at crab stage 3 were still undergoing megalopal pleopod loss, but by stage 6 adult pleopods were beginning to develop, as adult females of Petrolisthes are provided with paired pleopods on pleomeres 2-5. Despite the precocious appearance of gonopores, the division of the telson into the seven-plate condition of the adult appears not to have yet begun, as Brossi-Garcia \& Guimarães Moreira gave only setal counts for the telson in juvenile stages 1-11.

The first four crab stages were described by Paul et al. (1993) for Pisidia gordoni (Johnson, 1970) with pleopods of the second through fifth pleomeres reduced in the first crab stage. By the second stage, the posterior three pairs were absent or vestigial whereas, the second pair had been transformed into developing male gonopods in one specimen. However, in two other specimens, adjudged by the authors possibly to be females, complete pleopod loss by crab stage 3 was observed. At the fourth crab stage, the telson began to show indications of the seven-plated adult condition. Paul et al. (1993) also described the first three juvenile stages of Petrolisthes rufescens (Heller, 1861). In this species pleopod loss began with the molt to the first crab and no pleopods were present by crab stage 3. Paul et al. (1993) considered it more probable that their few specimens were incipient females rather than that a delay in the development of male gonopods occurred in this species. Division of the telson in $P$. rufescens, however, was already observable in the first crab stage and was nearly complete by the third crab stage.

Only the first crab stage was described for Allopetrolisthes angulosus (Guérin Méneville, 1835) by Wehrtmann et al. (1996). These authors reported pleopod reductions on pleomeres 2-6 (sic), but with the pleopod pair of pleomere 2 approximately three times larger than the remainder. A more significant difference was reported for the telson, where the full complement of five adult plates was already well defined.

In the development of male gonopods, Paul et al. (1993) noted that considerable similarity existed between brachyurans and porcellanids, but expressed the belief that this was another example of convergence. Our data are too meager to formulate any real comparisons with the transformations taking place among lithodids and porcellanids, but it is quite obvious that considerable heterochronic development occurs in both groups. 


\section{Zoeal phase}

Knowledge of zoeal development in the Porcellanidae is appreciably more complete. Despite their distinctive, very elongate rostral and posterolateral carapace spines, porcellanid zoeas were considered by early carcinologists essentially to be very similar to those of the Brachyura (Müller, 1863). However, only two characters might conceivably link the porcellanids to the Brachyura, i.e., the reduced, somewhat rod-shaped antennal exopod and the lack of a functional exopod on the third maxilliped (Williamson 1974). Only in Petrocheles spinosus Miers, 1876 , does the number of porcellanid zoeal stages exceed two, and only in this species do uropods develop before the megalopal stage. Wear (1965) described five zoeal stages for $P$. spinosus, with uropods developing in stage three, but with no pleopods developed in either the zoeal or megalopal stages. In all other porcellanids for which larval data are available, developing pleopods are present in ZII and become functional in the megalopal stage, only to be reduced or lost in subsequent juveniles stages. While paired, egg-bearing pleopods reappear in females, pleopods are completely absent in adult males unless the second pair develop as gonopods.

\section{Conclusions}

It is abundantly clear that there are a multitude of avenues of investigation remaining to be pursued before we can unravel the evolution of, and relationships within, the Anomura. Each bit of information, be it molecular, developmental, or morphological, contributes to our overall comprehension. Unquestionably, the evolution of a crab-like body form has occurred more than once. Whether each occurrence is equivalent to each other occurrence has yet to be ascertained. From our limited data, it appears that this body form arose independently in Lomis, the Porcellanidae, and the Lithodidae. It is most unlikely that there was a common precursor in the recent ancestral past, but certain morphological and developmental common trends weave a tantalizing thread.

In addition to the unsolved puzzles of asymme- try, pleopod loss and uropod specialization, this study also has not resolved the question of the plesiomorphy or apomorphy of direct development. Knowlton (1974) suggested that the basic unifiable sequence of metamorphic development in crustaceans could be reduced to three basic forms: nauplius, protozoea, and zoea. There has been considerable emphasis in recent years on the principal role of the nauplius larva in crustacean evolution (Björnberg 1986; Walossek \& Müller 1990, 1998; Slack et al. 1993; Walossek 1993; Dahms 2000). However, Scholtz (2000), after an extensive review of crustacean nauplii, has suggested that the free living nauplius of euphausiids and penaeids well may have evolved from an ancestral egg-nauplius, thus being secondarily derived. If Scholtz's hypothesis, in contrast to the opinions of Felgenhauer \& Abele (1983) and Martin \& Abele (1986), is substantiated, the free living penaeid nauplius and other attributes of the Dendrobranchiata, very well may not exhibit the most primitive of larval, megalopal and juvenile decapod characters. The concept of a secondarily derived, free-living nauplius also lends some credibility to Wolpert's (1994) hypothesis that direct development is ancestral. Similarly, some of the developmental trends that have surfaced during the present investigation might be more readily explained through the primitive nature of direct development.

From this study we have been able to demonstrate that pleonal tergal plate development does not proceed as had been previously hypothesized. And for some genera we have been able to trace what actually is occurring in these tergites in early developmental stages. This information, however, leads immediately to the question: why is it such a complicated pattern, and how did it evolve? For an answer, we can look only to the data currently available. The lithodid megalopal tergites are entire, as they are in all decapods known, and as they are in most adults. Why then does all the sundering occur in lithodids? Two or possibly three processes seem to be involved: division, decalcification/ dechitinization, and/or lack of calcium deposition. It is these processes that lead from the king to the hermit.

As has been demonstrated, in the most heavily calcified lithodid genera, Paralomis, Lopholithodes, 
Cryptolithodes, the pattern of tergal subdivision appears to restricted in tergites 3-5. The first and second tergites do not divide but instead fuse to form a single plate. In Paralomis minimal divisions in tergites 3-5 result in the tergites each represented by a single median and pair of lateral plates. There is no apparent decalcification except at the sutures delineating the plates. In the second crab stage of Lopholithodes, in addition to the division of tergites 3-5 into similar median and paired lateral plates, the accessory plates of tergite 3 have become delineated. Judging from the adult condition, we can assume that a similar division occurs in tergite 3 in Cryptolithodes; but at a later juvenile stage. In tergite 3 there is decalcification not only at the sutures separating the median and lateral plates, but in the area encircling each accessory plate. In both genera, tergites 4 and 5 undergo no further division and the only apparent areas of decalcification are at the sutures. We interpret these initial partitions and limited areas of calcium loss as the first of many steps on the evolutionary path to complete decalcification of pleonal tergites 2-5.

The steps along this pathway of decalcification are more apparent in the other genera of the Lithodinae as have been described in detail for species of Lithodes. In the Hapalogastrinae genus, Acantholithodes, where the megalopal tergites are also calcified, the process of decalcification is even further underway in crab stage 1 with prominently uncalcified areas separating tergites 1 and 2 and the latter now represented by a median and wellseparated paired lateral and marginal plates. Decalcification is even more apparent in tergites 3-5, with the integument of median and portions of the lateral plates now predominantely chitinous. Further decalcification and tergal identity loss can be followed in other genera.

Except for the Pylochelidae, for which we still do not have any substantive lárval, megalopal or juvenile data, the pleons of non-lithodid paguroids progress from chitinous, identifiable, entire tergal plates in the megalopae to partially chitinous, and ultimately, in many taxa, completely membranous integuments in subsequent crab stages, often with tergal identity lost, particularly on pleomeres 3-5. In some species at least, what have been referred to as lateral tergal plates, truly are remnants of the megalopal tergites, while in others the lateral "plates" on the left side of the pleon are simply thickenings of the integument for the attachment of the acetabulae of the pleopods. The range of variation in loss of tergal identity has been only meagerly investigated, but despite our present limited knowledge, it can confidently be said to be considerable. The direction unquestionably is toward loss, environmental influences not withstanding.

The megalopal/early juvenile data have shown additional directional changes as well. Ocular acicles, for example, are entirely absent in lithodid megalopae, as they are in a few, but not most other paguroids. In these few other paguroids, acicles develop in crab stages 1 or 2 , and they are never subsequently lost. Acicles, as seen in other paguroids, do not subsequently develop in lithodids, although some minor calcifications on the second ocular segments occasionally have been reported (cf. McLaughlin 1983). When ocular acicles are viewed from the developmental prospective, it is clear that it is not loss of acicles in the lithodids, but initial absence, with acicles being gained in other paguroids.

With the metamorphic molt to megalopa, the fourth pereiopods, which have begun developing in the zoeal phase, emerge, in all lithodids, in the primitive condition of functional walking legs. In other paguroids, the fourth pereiopods, if they have begun forming in the zoeal phase, emerge at the megalopal molt as reduced, modified, and specialized appendages.

In both lithodids and other paguroids, a primitive unarmed telson is seen in the megalopa. In lithodids it remains unarmed in crab stage 1 , but will in some species develop spinules on the dorsal surface in crab stage 2 . In contrast, other paguroids progress from the unarmed megalopal telson frequently to a telson armed with marginal spines or spinules with the molt to crab stage 1 . While the lithodid telson continues to be reduced in subsequent crab stages, it remains a well developed, often prominently armed structure in other paguroid crab stages. Clearly the transformation again is from simple (plesiomorphic) to complex (apomorphic).

From the larval phase data, general directional inferences also can be made. Although variable, the lithodid pleon in the last zoeal stage frequently 
still exhibits the presumably more primitive conditions of no separation or only partial separation of the sixth pleomere. Most frequently, at least in the Paguridae, distinct delineation of this pleomere is complete by the third zoeal stage.

Telsonal processes, if they change in number during the zoeal stages, usually increase by adding processes medially. However, the evolutionary transformation in telson processes appears to progress from "more to less", the higher initial (ZI) number indicative of the more primitive condition. Lithodid zoeas most frequently hatch with eight to ten processes, whereas, the number in pagurids is commonly seven. These processes, primitively articulated in early zoeal stages, for the most part remain articulated in the last zoeal stages in lithodids, but frequently become fused (apomorphic) in paguroids, particularly in members of the Paguridae.

The evidence obtained from the megalopal/early juvenile development of lithodid pleonal tergites has demonstrated unequivocally that a transition from a shell-dwelling hermit crab to a fully calcified lithodid crab could not possibly have happened in the ways previously hypothesized. The supplemental juvenile, megalopal, and larval data presented here also bolster this finding. Both support the sundering and decalcification hypothesis of McLaughlin \& Lemaitre (1997). In contrast, evidence purportedly confirming the more recent transitional hypothesis of "hermit to king" has been shown to be inaccurate and/or incorrectly interpreted.

Admittedly, the current investigation has not fully traced the complex evolutionary pathways involved in decalcification, or adequately addressed loss of symmetry. Nevertheless, to ignore its findings and blindly insist on acceptance of the "... [erroneous] hypotheses proposed by several generations of taxonomists ..." (Morrison et al. 2002: 349), albeit great minds of their times, would be a major step backwards for anomuran systematics. As the earth has been shown not to be flat, we have shown that the lowly hermit crab did not evolve into a mighty king.

\section{Acknowledgements}

The authors again recognize, with heartfelt appreciation, the contributions of larval lithodid series by our numerous colleagues that made all of the initial studies possible. Dr. Thomas Shirley,
University of Alaska, recently contributed another important element to the investigation in providing the zoeal and megalopal stages of Paralithodes camtschaticus. Dr. A. J. Provenzano, Jr., Old Dominion University, allowed us to report his unpublished data on development in Lomis hirta. These contributions also are most gratefully acknowledged. Continued gratitude is due Dr. Robert $\mathrm{H}$. Gore, who painstakingly reviewed an earlier draft of the manuscript and provided valuable suggestions for its present direction. The questions raised and recommendations made by Drs Klaus Anger, Peter Ng, and Stefan Richter have been most helpful. Special thanks go to Rose A. Gulledge, Department of Systematic Biology, National Museum of Natural History, for her expert assistance with the illustrations, tables and literature searches. This is, in part, a scientific contribution from the Shannon Point Marine Center, Western Washington University.

\section{References}

Ageno M. 1972. On molecular asymmetry in living organisms. J. Theo-r. Biol. 37: 187-192.

Agassiz A. 1875. Instinct? in hermit crabs. Amer. J. Sci. 10: 290-291.

Aguirre-Urreta MB, Olivero EB. 1992. A Cretaceous hermit crab from Antarctica: predatory activities and bryozoan symbiosis. Antarctic Sci. 4: 207-214.

Al-Aidaroos A, Williamson DI. 1989. Larval development of the land hermit crab Coenobita scaevola (Forskål, 1775) (Crustacea: Anomura: Coenobitidae) reared in the laboratory. J. Nat. Hist. 23: 111-128.

Albornoz L, Wehrtmann IS. 1996. Aspects of the reproductive biology of Petrolisthes laevigatus (Guérin, 1835) (Decapoda, Anomura, Porcellanidae). Part II. Description of the larval development, including the first crab stage, cultivated under laboratory conditions. Arch. Fish. Mar. Res. 43: 137-157.

Anger K. 1989. Growth and exuvial loss during larval and early juvenile development of the hermit crab Pagurus bernhardus, reared in the laboratory. Mar. Biol. 103: 503-511.

Anger K. 1996. Physiological and biochemical changes during lecithotrophic larval development and early juvenile growth in the northern stone crab, Lithodes maja (Decapoda: Anomura). Mar. Biol. 126: 283-296.

Anger K. 2001. The biology of decapod crustacean larvae. Crust. Issues 14: 1-419.

Baba K, Fukuda Y. 1985. Larval development of the hermit crab Diogenes nitidimanus Terao, 1913 (Crustacea: Anomura: Diogenidae) reared in the laboratory. Mem. Fac. Educ. Kumamoto Univ. Nat. Sci. 34: 5-17.

Barnard KH. 1950. Descriptive catalogue of South African decapod Crustacea (crabs and shrimps). Ann. So. Afr. Mus. 38: $1-837$.

Benedict JE. 1895. Descriptions of new genera and species of crabs of the family Lithodidae with notes on the young of Lithodes camtschaticus and Lithodes brevipes. Proc. U.S. Nat. Mus. 17: 479-488. 
Björnberg TKS. 1986. The rejected nauplius: a commentary. Syllogeus 58: 232-236.

Blackstone NW. 1989. Size, shell-living and carcinization in geographic populations of a hermit crab, Pagurus hirsutiusculus. J. Zool. Lond. 217: 477-490.

Boas JEV. 1880a. II. Wissenschaftliche Mittheilungen. 1 Lithodes und Pagurus. Zool. Anz. 3: 349-352.

Boas JEV. 1880b. Studier over decapodernes Slægtskabsforhold. $K$. danske Vidensk. Selsk. Skr. (5)6: 25-210.

Boas JEV. 1924. Die verwandtschaftliche Stellung der Gattung Lithodes. K. danske Vidensk. Selsk. Skr. 4(4): 1-34.

Boas JEV. 1926. Zur Kenntnis symmetrischer Paguriden. $K$. danske Vidensk. Selsk. Skr. 5(6): 1-52.

Bookhout CG. 1972. Larval development of the hermit crab, Pagurus alatus Fabricius, reared in the laboratory (Decapoda, Paguridae). Crustaceana 22: 215- 238.

Boone L. 1926. A new family of Crustacea. Preliminary technical description. N.Y. Zool. Soc. Bull. 29: 73.

Borradaile LA. 1916. Crustacea. Part II. Porcellanopagurus: An instance of carcinization. In: British Antarctic ("Terra Nova") Expedition, 1910. Natural history report. Zoology 3(3): 111-126.

Bosc LAG. 1802. Histoire Naturelle des Crustacés, contenant leur description et leurs meours; avec figures dessinée n'après nature. 2: 1-296. Paris: De Guilleminet,

Bouvier E-L. 1894a. Sur la signification de Hapalogaster dans l'évolution des Lithodinés. C. R. Somm. Séanc. Soc. Philom. 18: $1-5$.

Bouvier E-L. 1894b. Sur la transformation des Paguriens en crabes anomures de la sous-famille des Lithodinés. $C . R$. Hebd. Séanc. Acad. Sci. 119: 350-352.

Bouvier E-L. 1895. Recherches sur les affinités des Lithodes $\&$ des Lomis avec les Pagurides. Annls. Sci. Nat. (7)18:157213.

Bouvier E-L. 1897. La transformation des Bernards l'Ermite en Lithodes. Naturaliste (2)19(230): 41-43.

Bouvier E-L. 1940. Décapodes Marcheurs. 1-404. Faune de France 37. Paris: P. Lechevalier.

Boyko CB, Harvey AW. 1999. Crustacea Decapoda: Albuneidae and Hippidae of the tropical Indo-West Pacific region. In: Crosnier A. (ed.). Résults des Campagnes MUSORSTOM, 20. Mém. Mus. Natn. Hist. Nat. 180: 379-460.

Brandt JF. 1848. Die Gattung Lithodes Latreille nebst vier neuer ihr verwandten von Wosnessenski entdeckten, als Typen einer besondern Unterabtheilung (Tribus Lithodea) der Edward'shen Anomuren. Bull. Cl.Phys.-Math. Acad. Sci. St. Pétersbourg 7: 171-176.

Brandt JF. 1850. Vorlaüfige Bemerkungen über eine aus zwei noch unbeschreobenen Gattungen und Arten gebildete Unterabtheilung (Hapalogastrica) der Tribus Lithodea, begleitet von einer Charakteristik der eben genannten Tribus der Anomuren. Bull. Cl. Phys.-Math. Acad. Sci. St. Pétersbourg 8: 266-269.

Brandt JF. 1851. Krebse. In: Middendorff ATh v. Reise in den äussersten Norden und Osten Sibiriens während der.Jahre 1843 und 1844. 2(1) (Zoolo-gie): 77-148.

Brandt JF. 1853. Ueber eine neue Art der Gattung Crypto- lithodes (Cryptolithodes sitchensis). Bull. Cl. Phys.-Math. Acad. Sci. St. Pétersbourg 11: 653-654.

Brodie R.J. 1999. Ontogeny of shell-related behaviors and transition to land in the terrestrial hermit crab Coenobita compressus H. Milne Edwards. J. Exp. Mar. Biol. Ecol. 241: 67-80.

Brodie R, Harvey AW. 2001. Larval development of the hermit crab Coenobita compressus $\mathrm{H}$. Milne Edwards reared in the laboratory. J. Crust. Biol. 21: 715-733.

Brooks DR, Wiley EO. 1985. Theories and methods in different approaches to phylogenetic systematics. Cladistics 1: 112.

Brossi-Garcia AL. 1987a. Morphology of the larval stages of Clibanarius sclopetarius (Herbst, 1796) (Decapoda, Diogenidae) reared in the laboratory. Crustaceana 52: 251275.

Brossi-Garcia AL. 1987b. Juvenile development of Clibanarius sclopetarius (Herbst, 1796) (Crustacea: Paguridea: Diogenidae) in the laboratory. J. Crust. Biol. 7: 338-357.

Brossi-Garcia AL. 1988. Juvenile development of Clibanarius vittatus (Bosc, 1802) (Decapoda, Anomura), in the laboratory. Crustaceana 54: 294-313.

Brossi-Garcia AL, Guimarães Moreira R. 1996. Estudos biométricos e morfológicos dos primeiros estágios juvenis de Petrolisthes armatus (Gibbes, 1850) (Decapoda, Porcellanidae) em laboratório. Rev. Brasil. Biol. 56: 231-243.

Brossi-Garcia AL, Hebling NJ. 1983. Desenvolvimento pósembrionario de Clibanarius antillensis Stimpson, 1859 (Crustacea, Diogenidae), em laboratório. Bolet. Zool. Univ. São. Paulo 6: 89-111.

Bryant HN. 1992. The polarization of character transformations in phylogenetic systematics: role of axiomatic and auxillary assumptions. Syst. Zool. 40 (1991): 433-445.

Bryant HN. 1997. Hypothetical ancestors and rooting in cladistic analysis. Cladistics 13: 337-348.

Cabrera Jiménez JA. 1966. Le metamórfosis larvaria de Clibanarius vittatus (Bosc): Descripción de los primeros estadios y efecto de la temperatura en la supervivencia. Tésis, Universidad Nacional Autómona de México, 48 pp.

Campodonico I. 1971. Desarrollo larval de la centolla Lithodes antarctica Jacquinot en condiciones de laboratorio. (Crustacea Decapoda, Anomura: Lithodidae). Ans. Inst. Pat. 2:181190.

Campodonico I, Guzmán L. 1981. Larval development of Paralomis granulosa (Jacquinot) under laboratory conditions (Decapoda, Anomura, Lithodidae). Crustaceana 40: 272-285.

Carvacho A. 1988. Développement juvénile de Pagurus bernhardus L. (Crustacea Decapoda). Cah. Biol. Mar. 29: 109-133.

Chai FS. 1974. Classification and adaptive significance of developmental patterns in marine invertebrates. Thal. Jugoslavica 10: 121-130.

Charmantier G, Giménez L, Charmantier-Daures M, Anger K. 2002. Ontogeny of osmoregulation, physiological plasticity and larval export strategy in the grapsid crab Chasmagnathus granulata (Crustacea, Decapoda). Mar. Ecol. Prog. Ser. 220: 185-194.

Chippendale AK, Palmer AR. 1994. Persistence of subtle de- 
partures from symmerty over multiple molts in individual brachyuran crabs: relevance to developmental stability. 187201. In: Markow TA. (ed.). Developmental Instability: Its Origins and Evolutionary Implications: Dordrecht, The Netherlands: Kluwer Academic Publishers.

Christoffersen ML. 1987. Phylogenetic relationships of hippolytid genera, with an assignment of new families for the Crangonoidea and Alpheoidea (Crustacea, Decapoda, Caridea). Cladistics 3: 348-362.

Christoffersen ML. 1988a. Phylogenetic systematics of the Eucarida (Crustacea Malacostraca). Revta. Bras. Zool. 5: 325351.

Christoffersen ML. 1988b. Genealogy and phylogenetic classification of the new world Crangonidae (Crustacea, Caridea), with a new species and new records for the southwestern Atlantic. Revta. Nordest. Biol. 6: 43-69.

Christoffersen ML. 1989. Phylogeny and classification of the Pandaloidea (Crustacea, Caridea). Cladistics 5: 259-274.

Christoffersen ML. 1995. Cladistic taxonomy, phylogenetic systematics, and evolutionary ranking. Syst. Biol. 44: 440454.

Clark PF. 2000. Interpreting patterns in chaetotaxy and segmentation associated with abbreviated brachyuran zoeal development. Invert. Reprod. Develop. 38: 171-181.

Clark PF, Calazans D. 1999. A review of the decapod and euphausiid larval terms, stage and phase. Zoea 6(2): 2-9.

Clark PF, Webber WR. 1991. A redescription of Macrocheira kaempferi (Temminck, 1836) zoeas with a discussion of the classification of the Majoidea Samouelle, 1819 (Crustacea: Brachyura). J. Nat. Hist. 25: 1259-1279.

Clark PF, Calazans DK, Rodrigues SS. 1998. Libinia spinosa H. Milne Edwards, 1834 (Crustacea: Majidae: Pisinae): a reappraisal of larval characters from laboratory reared material. Invert. Reprod. Develop. 33: 145-157.

Coffin HG. 1957. A new southern form of "Pagurus hirsutiusculus" (Dana) (Crustacea, Decapoda). Walla Walla Coll. Publs. Dep. Biol. Sci. 21: 1-8.

Cormie AK. 1993. The morphology of the first zoea stage of Lomis hirta (Lamarck, 1818) (Decapoda, Lomisidae). Crustaceana 64: 249-255.

Crain JA, McLaughlin PA. 1993. Larval, postlarval, and early juvenile development in Pagurus venturensis Coffin, 1957 (Decapoda: Anomura: Paguridae) reared in the laboratory, with a redescription of the adult. Bull. Mar. Sci. 53 (1993): 985-1012.

Crain JA, McLaughlin PA. 2000a. Larval and early juvenile development in the Lithodidae (Decapoda: Anomura: Paguroidea) reared under laboratory conditions. 1 . Subfamily Lithodinae: Lopholithodes mandtii Brandt, 1848. Invert. Reprod. Develop. 37: 43-59.

Crain JA, McLaughlin PA. 2000b. Larval and early juvenile development in the Lithodidae (Decapoda: Anomura: Paguroidea) reared under laboratory conditions. 2. Hapalogastrinae: Placetron wosnessenskii Schalfeew, 1892, with notes on comparative development within the subfamilies of the Lithodidae. Invert. Reprod. Develop. 37: 113127.

Cunningham CW, Blackstone NW, Buss LW. 1992. Evolu- tion of king crabs from hermit crab ancestors. Nature 355 539-542.

Dahms H-U. 2000. Phylogenetic implications of the crustacean nauplius. Hydrobiologia 417: 91-99.

Dana JD. 1851. Conspectus crustaceorum quae in orbis terrarum circumnavigatione, Carolo Wilkes e classe reipublicae foederatae duce, lexit et descripsit. (Preprint from) Proc. Acad. Nat. Sci. Philad. 5: 267-272.

Dana JD. 1852. Conspectus crustaceorum, etc., Conspectus of the Crustacea of the Exploring Expedition under Capt. Wilkes, U.S.N., including the Paguridea, continued, the Megalopidea, and the Macroura. Paguridea, continued, and subtribe Megalopidea. (Preprint from) Proc. Acad. Nat. Sci. Philad. 6: 6-28, 1854.

Dawirs RR, Puschel C, Schorn F. 1986. Temperature and growth in Carcinus maenas L. (Decapoda: Portunidae) larvae reared in the laboratory from hatching through metamorphosis. J. Exp. Mar. Biol. Ecol. 100: 47-74.

Dawson EW, Yaldwyn JC. 1985. King crabs of world or the world of king crabs: an overview of identity and distribution-with illustrated diagnostic keys to the genera of the Lithodidae and to the species of Lithodes. Proc. Internatn. King Crab Sym., Jan. 1985: 69-106.

Dechancé M. 1958. Caractérisation de la glaucothoë et des premiers stades Pagure chez Clibanarius misanthropus (Risso) (Crust. Décapode Anomoure). C.R. Acad. Sci. 246: 839-842.

Dechancé M. 1961. Nombre et caractères des stades larvaires dans le genre Dardanus (Crustacés Décapode Paguride). C.R. Acad. Sci. 253: 529-531.

Dechancé M. 1962. Remarques sur les premiers stades larvaires de plusieurs espèces indopacifiques du genre Dardanus (Crustacés Décapodes Pagurides). Bull. Mus. Natl Hist. Nat. (2) 34(1): 82-94.

Dechancé M. 1963. Développement direct chez un Paguride, Paguristes abbreviatus Dechancé, et remarques sur le développement des Paguristes. Bull. Mus. Natn. Hist. Nat. (2)35: 488-495.

Dechancé M, Forest J. 1958. Les glaucothoés de Catapaguroides timidus (Roux) et de Clibanarius erythropus (Latreille). Remarques sur le stade post-larvaire des Pagurides. Bull. Soc. Zool. Fr. 83: 274-293.

Elwood RW, Neil SJ. 1992. Assessments and decisions. $A$ study of information gathering by hermit crabs. $\mathrm{xi}+192 \mathrm{pp}$. London, New York, Tokyo: Chapman \& Hall.

Emmel VA. 1908. The experimental control of asymmetry at different stages in the development of the lobster. J. Exp. Zool. 5: 471-484.

Fabricius JC. 1775. Systema entomologiae, sistens Insectorum classes, ordines, genera, species, adjectis synonymis, locis, descriptionibus, observationibus. xxxii +832 pp. Flensburgi et Lipsiae: Officina Libraria Kortii.

Felder DL, Martin JW, Goy JW. 1985. Patterns in early postlarval development of decapods. Crust. Issues 2: 163225.

Feldmann RM. 1998. Paralomis debodeorum, a new species of decapod crustacean from the Miocene of New Zealand: first notice of the Lithodidae in the fossil record. New Lealand J. Geol. Geophys. 41: 35-38. 
Felgenhauer BE, Abele LG. 1983. Phylogenetic relationships among shrimp-like decapods. Crust. Issues 1: 291-311.

Filhol H. 1885a. Description d'un nouveau genre de Crustacés provenant de la Nouvelle-Zélande. Bull. Soc. Philom. Paris (7)9: 47-48.

Filhol H. 1885b. Considérations relatives a la faune des Crustacés de la Nouvelle-Zélande. Bibl. Éc. H. Ét., Sect. Sci. Nat. 30(2): 3-60.

Fong DW, Kane TC, Culver DC. 1995. Vestigialization and loss of nonfunctional characters. Annu. Rev. Ecol. Syst. 26: 249-268.

Forest J. 1954. Sur les premiers stades post-larvaires du Pagure Dardanus pectinatus (Ortmann). C.R. Hebd. Séanc. Acad. Sci. 239: 1697-1699.

Forest J. 1987. Les Pylochelidae ou "Pagures symetriques" (Crustacea Coenobitoidea). In: Résultats des campagnes MUSORSTOM. Mém. Mus. Natn. Hist. Nat. A Zool. 137: 1254.

Forest J, de Saint Laurent M. 1975. Présence dans la faune actuelle d'un représentant du groupe mésoziquedes Glyphéides: Neoglyphea inopinata gen. nov., sp. nov. (Crustacea Decapoda Glypheidae). C. R. Hebd. Séanc. Acad. Sci. Paris (D) 281: 155-158.

Forest J, de Saint Laurent M, McLaughlin PA, Lemaitre R. 2000. The marine fauna of New Zealand: Paguridea (Decapoda: Anomura) exclusive of the Lithodidae. NIWA Biodiversity Mem. 114: 1-250.

Fujita Y, Shokita S, Osawa M. 2002. Complete larval development of Petrolisthes unilobatus reared under laboratory conditions (Decapoda: Anomura: Porcellanidae). J. Crust. Biol. 22: 567-580.

Fukuda Y. 1995. Morphological evolution from shrimp-shaped to crab-shaped larvae in the decapod Crustaceana [sic]: a hypothesis based on larval and postlarval development. Benthos Res. 48: 13-27 (in Japanese with English abstract).

Gebauer P, Paschke K, Anger K. 2002. Metamorphosis in a semiterrestrial crab, Sesarma curacaoense: intra- and interspecific settlement cues from adult odors. J. Exp. Mar. Biol. Ecol. 268: 1-12.

Gherardi F. 1995. Hermit crab larval behavior: depth regulation in Discorsopagurus schmitti. J. Exp. Mar. Biol. Ecol. 192: 107-123.

Gherardi F. 1996a. Gastropod shells or polychaete tubes? The hemit crab Discorsopagurus schmitti's housing problem. Ecoscience 3: 154-164.

Gherardi F. 1996b. Non-conventional hermit crabs: pros and cons of a sessile, tube-dwelling life in Discorsopagurus schmitti (Stevens). J. Exp. Mar. Biol. Ecol. 202: 119-136.

Gherardi F, McLaughlin PA. 1995. Larval and early juvenile development of the tube-dwelling hermit crab Discorsopagurus schmitti (Stevens) (Decapoda: Paguridae) reared in the laboratory. J. Crust. Biol. 15: 258-279.

Gibbes LR. 1850. On the carcinological collections of the United States, and an enumeration of species contained in them, with notes on the most remarkable, and descriptions of new species. Proc. Amer. Assoc. Adv. Sci. 3:167-201.

Goffinet G, Jeuniaux Ch. 1994. Le tégument: morphologie et biochimie. In: Grassé P-P, Forest J. (eds.). Traité de zoologie.
Anatomie, systématique, biologie, 7(1): 49-90 Paris etc.: Masson.

Goldstein B, Bookhout CG. 1972. The larval development of Pagurus prideauxi Leach, 1814, under laboratory conditions (Decapoda, Paguridae). Crustaceana 23: 263-281.

Gore RH. 1985. Molting and growth in decapod larvae. Crust. Issues 2: 1-65.

Gore RH, Scotto LE. 1983. Studies on decapod Crustacea from the Indian River region of Florida XXVII. Phimochirus holthuisi (Provenzano, 1961) (Anomura: Paguridae): The complete larval development under laboratory conditions, and the systematic relationships of its larvae. J. Crust. Biol. 3: 93-116.

Gould SJ. 1992. We are all monkeys' uncles. Nat. Hist. 6/92 14-21.

Goy JW, Provenzano Jr AJ. 1978. Larval development of the rare burrowing mud shrimp Naushonia crangonoides Kingsley (Decapoda; Thalassinidea; Laomediidae). Biol. Bull. 154: 241-261.

Goy JW, Provenzano Jr AJ. 1979. Juvenile morphology of the rare burrowing mud shrimp Naushonia crangonoides Kingsley, with a review of the genus Naushonia (Decapoda: Thalassinidea: Laomediidae). Proc. Biol. Soc. Wash 92: 339359.

Grahame JH, Emlen JM, Freeman DC, Leamy LJ, Kieser JA. 1998. Directional asymmetry and the measurement of developmental instability. Biol. J. Linn. Soc. 64: 1-16.

Greenaway P. 1985. Calcium balance and moulting in the Crustacea. Biol. Rev. 60: 425-454.

Guérin-Méneville RE. 1835. Observations sur les Porcellanes. Bull. Soc. Sci. Nat. Fr. 1835: 115-116.

Gurney R. 1942. Larvae of decapod Crustacea. 129: 1-306 London: Ray Society.

De Haan W. 1833-1850. Crustacea. In: von Siebold PF. Fauna Japonica sive descriptio animalium, quae in itinere per Japoniam, jussu et auspiciis superiorum, qui summum in India Batava Imperium tenent, suscepto, annis 1823-1830 collegit, notis, observationibus et adumbrationibus illustravit. Fasc. 1-8 ix-xvi, vii-xvii, i-xxxi, 1-243, pls. I-LV, 1-2, A-Q. Amstelodami: apud auctorem, Lugduni Batavorum \& J. Mülleer \& Co.

Hall BG. 2001. Phylogenetic trees made easy, a how-to manual for molecular biologists. 179 pp. Sunderland, MA: Sinauer Associates. Inc.

Harms JW. 1932. Die Realisation von Genen und die consective Adaptation. II. Birgus latro L. als Landkrebs und seine Beziehungen zu den Coenobiten. Zeitsch. Wiss. Zool. 140: 167-288.

Harms JW. 1938. Lebensablauf und Stammesgeschichte des Birgus latro L. von der Weihnachtsinsel. Zeitsch. Naturwiss. Jena 75 : 1-34.

Hart JFL. 1937. Larval and adult stages of British Columbia Anomura. Can. J. Res. D 15: 179-220.

Hart JFL. 1965. Life history and larval development of Cryptolithodes typicus Brandt (Decapoda, Anomura) from British Columbia. Crustaceana 8: 255- 276.

Harvey AW. 1992. Abbreviated larval development in the Australian terrestrial hermit crab Coenobita variabilis McCulloch 
(Anomura: Coenobitidae). J. Crust. Biol. 12: 196-209.

Harvey AW. 1996. Delayed metamorphosis in Florida hermit crabs: multiple cues and constraints (Crustacea: Decapoda: Paguridae and Diogenidae). Mar. Ecol. Prog. Ser. 141: 2736.

Harvey AW. 1998. Genes for asymmetry easily overruled. $\mathrm{Na}$ ture 392: 345-346.

Hawkins JA, Hughes CE, Scotland RW. 1997. Primary homology assessment, characters and character states. Cladistics 13: 175-283.

Haynes EB. 1982. Description of larvae of the golden king crab, Lithodes aequispina, reared in the laboratory. Fish. Bull. 80: 305-313.

Haynes EB. 1984. Early zoeal stages of Placetron wosnessenskii and Rhinolithodes wosnessenskii (Decapoda, Anomura, Lithodidae) and review of lithodid larvae of the northern North Pacific Ocean. Fish. Bull. 82: 315-324.

Haynes EB. 1993. Stage-I zoeae of laboratory-hatched Lopholithodes mandtii (Decapoda, Anomura, Lithodidae). Fish. Bull. 91: 379-381.

IIcld EE. 1963. Moulting behaviour of Birgus latro. Nature 200 799-800.

Heller C. 1861. Beiträge zur Crustaceen-Fauna des Rothen Meers, II. Sitz-Ber. Math-Phys. Kl. Akad. Wiss. Wien 44: 241 295.

Henderson JR. 1886. The decapod and schizopod Crustacea of the Firth of Clyde. Trans. Nat. Hist. Soc. Glasgow 1885 315- 353.

Henderson JR. 1888. Report on the Anomura collected by H.M.S. Challenger during the years 1873-76. Scientific Results of the Exploratory Voyage of HMS Challenger, (Zoology) 27: 1-221.

Iennig, W. 1966. Phylogenetic systematics. Urbana: University of Illinois Press.

Hickmann CS. 1999. Larvae in invertebrate development and evolution. 21-59. In: Hall BK, Wake MK. (eds.). The origin and evolution of larval forms: New York, etc.: Academic Press.

Hoffman EG. 1968. Description of laboratory-reared larvae of Paralithodes platypus (Decapoda, Anomura, Lithodidae). J. I Fish. Res. Bd Can. 25:439-455.

Holmes SJ. 1895. Notes on west American Crustacea. Proc Calif. Acad. Sci. 4: 563-588.

Hombron JB, Jacquinot H. 1846. Atlas d'Histoire Naturelle Zoologie par MM. Hombron et Jacquinot, chirurgiens de l'expédition. In: Voyage au pole sud et dans l'Océanie sur les corvettes l'Astrolabe et la Zélée exécuté par ordre du roi pendant les années 1837-1838-1839-1840 sous le commandement de M. Dumont-D'Urville capitaine de vaisseau publié sous les auspices de département de marine et sous la direction superieure de M. Jacquinot, capitaine de Vaisseau, commandant de la Zélée. Crustacés. pis. 1-9. Paris: Gide et Cie.

Hong SY. 1969. The larval development of Pagurus lanuginosus de Haan (Crustacea, Anomura) reared in the laboratory. Bull. Korean Fish. Soc. 2: 1-15.

Hong SY. 1981. The larvae of Pagurus dubius (Ortman) [sic] (Decapoda, Paguridae) reared in the laboratory. Bull. Natn. Fish. Univ. Busan 21(2): 1-11.
Hyden FM, Forest J. 1980. An in situ hermit crab from the early Miocene of southern New Zealand. Palaeontol. 23: 471474.

Imafuku M. 1993. Observations on the internal asymmetry of the sternal artery and the cheliped asymmetry in selected decapod crustaceans. Crus-t. Res. 22: 35-43.

Imafuku M. 1994. Response of hermit crabs to sinistral shells. J. Ethol. 12: 107-114.

Ingle RW. 1990. Larval and post-larval development of Anapagurus chiroacanthus (Lilljeborg, 1855) Anomura: Paguroidea: Paguridae. Bull. Br. Mus. Nat. Hist. (Zool.) 56: 105-134.

Jackson HG. 1913. Eupagurus. Liverpool Mar. Biol. Comm. Mem. 21: 1-79.

Johnson DS. 1970. The Galatheidae (Crustacea: Decapoda) of Singapore and adjacent waters. Bull. Natn. Mus. St. Singapore 35: 1-44.

Kaestner A. 1970. Invertebrate Zoology, 3: 1-523. New York: Wiley Interscience.

Kim MH, Hong SY. 2000. Larval development of Cryptolithodes expansus Miers (Decapoda: Anomura: Lithodidae) reared in the laboratory. Proc. Biol. Soc. Wash. 113: 54-65.

Klingenberg CP, McIntyre GS, Zaklan SD. 1998. Left-right asymmetry of fly wings and the evolution of body axes. Proc. Roy. Soc. Lond. B 265: 1255-1259.

Kluge AG. 1985. Ontogeny and phylogenetic systematics. Cladistics 1: 13-27.

Kluge AG. 1988. The characterization of ontogeny. 58-81. In: Humphries CJ. (ed.). Ontogeny and Systematics: New York: Columbia University Press.

Kluge AG, Strauss RE. 1985. Ontogeny and systematics. Ann. Rev. Ecol. Syst. 16: 247-268.

Knowlton RE. 1974. Larval developmental processes and controlling facators in decapod Crustacea, with emphasis on Caridea. Thal. Jugoslavica 10(1/2): 139-158.

Koenemann S, Schram FR. 2002. The limitations of ontogenetic data in phylogenetic analyses. Contr. Zool. 71: 47-65.

Konishi K. 1986. Larval development of the stone crab, Hapalogaster dentata (DeHaan, 1844) (Crustacea: Anomura: Lithodidae) reared in the laboratory. J. Fac. Sci., Hokkaido Univ. (4) Zool. 24: 155-172.

Konishi K, Imafuku M. 2000. Hatchling of the symmetrical hermit crab Pomatocheles jeffreysii Miers, 1879: the first information on pylochelid larva (Anomura: Pylochelidae). Crust. Res. 29: 65-69.

Konishi K, Quintana R. 1987. The larval stages of Pagurus brachiomastus (Thallwitz, 1892) (Crustacea: Anomura) reared in the laboratory. Zool. Sci. 4: 349-365.

Konishi K, Quintana R. 1988. The larval stages of three pagurid crabs (Crustacea: Anomura: Paguridae) from Hokkaido, Japan. Zool. Sci-. 5: 4 63-482.

Konishi K, Taishaku H. 1994. Larval development in Paralomis hystrix (De Haan, 1846) (Crustacea, Anomura, Lithodidae) under laboratory conditions. Bull. Natn. Res. Inst. Aquaculture 23: 43-54.

Krauss F. 1988. An empirical evaluation of the use of the ontogenetic polarization criterion in phylogenetic inference. Syst. Zool. 37: 106- 141. 
Kurata H, 1956. The larval stages of Paralithodes brevipes (Decapoda, Anomura). Bull. Hokkaido Reg. Fish. Res. Lab. 14: 25-34.

Kurata H. 1960. Last stage zoea of Paralithodes with intermediate form between normal last stage zoea and glaucothoe. Bull. Hokkaido Reg. Fish. Res. Lab. 22: 49-56.

Kurata H. 1962. Larvae of decapod Crustacea of Hokkaido. 5 Paguridae (Anomura). Bull. Hokkaido Reg. Fish. Res. Lab. 28: $24-48$.

Kurata H. 1964. Larvae of decapod Crustacea of Hokkaido. 6. Lithodidae (Anomura). Bull. Hokkaido Reg. Fish. Res. Lab. 28: $49-65$.

Lamarck JBPA. [Monet, chevalier de] 1818. Histoire naturelle des animaux sans vertèbres, présentant leurs caractéres généraux et particuliers de ces animaux, leur distribution, leurs classes, leurs familles, leurs genres, et la citation des princiales espèces qui s'y rapportent; précédée d'une introduction offrant la détermination des caractéres essential de l'animal, sa distinction du végétal et des autres corps naturels, enfin, l'exposition des principes fondamentaus de zoologie. 5: 1-612. Paris: Déterville \& Verdiére.

Lang WH, Young AM. 1977. The larval development of Clibanarius vittatus (Bosc) (Crustacea: Decapoda; Diogenidae) reared in the laboratory. Biol. Bull. 152: 84-104.

Latreille PA. 1806. Genera Crustaceorum et Insectorum secundum ordinem naturalem in familias disposita, iconibus exemplisque plurimis explicata. 1: 1-302 Parisiis et Argentorati: Treuttel et Würtz.

Lebour MV. 1934. Larval Crustacea (Decapoda and Stomatopoda) Expedition S.A.P. Prince Leopold of Belguim, Duke of Brabant, to the extreme east (1932). Bull. Mus. Hist. Nat. Belg. 10(8): 1-24.

Leach WE. 1815. Malacostraca Podophthalmata Britanniae; or descriptions of such British species of the Linnean genus Cancer as have their eyes elevated on footstalks. $124 \mathrm{pp}$. London.

Lemaitre R, McLaughlin PA. 1992. Descriptions of megalopa and juveniles of Sympagurus dimorphus (Studer, 1883), with an account of the Parapaguridae (Crustacea: Anomura: Paguroidea) from Antarctic and Subantarctic waters. J. Nat. Hist. 26: 745-768.

Lilljeborg W. 1855. Om Hafs-Crustaceer vid Kullaberg i Skåne. (Crustacea marina ad Kullaberg in Scania mense Julii 1852 collecta.) Ofvers. Vetensk. Akad. Forhandl. 12: 117-138.

Linnaeus C. 1758. Systema naturae per regna tria naturae, secundum classes, ordines, genera, species, cum characteribus, differentiis, synonymis locis. (ed. 10) 1: 1-824. Holmiae: Laurentii Salvii.

Mabee PM. 1989. An empirical rejection of the ontogenetic polarity criterion. Cladistics 5: 409-416.

Mabee PM. 1996. Reassessing the ontogenetic criterion. A response to Patterson. Cladistics 12: 169-176.

MacDonald JD, Pike RB, Williamson DI. 1957. Larvae of the British species of Diogenes, Pagurus, Anapagurus and Lithodes (Crustaca, Decapoda). Proc. Zool. Soc. Lond. 128: 209-257.

Macpherson E. 1988. Revision of the family Lithodidae
Samouelle, 1819 (Crustacea, Decapoda, Anomura) in the Atlantic Ocean. Monografias de Zoologia Marina. 2: 1-153.

Maddison WP. 1993. Missing data versus missing characters in phylogenetic analysis. Syst. Biol. 42: 576-581.

Maddison WP, Maddison DR. 1992. MacClade, version 3. Analysis of phylogeny and character evolution. Sunderland, MA: Sinauer Associates, Inc..

Maddison WP, Donoghue MJ, Maddison DR. 1984. Outgroup analysis and parsimony. Syst. Zool. 33: 83-103.

Makarov VV. 1938. Rakoobraznyey. Anomura. [Crustacés Décapodes anomures]. In: A.A. Shtakel'berg (ed.), Fauna SSSR, (n. ser.) 16(10)(3): 1-324. [Fauna of U.S.S.R. Crustacea, Anomura, 10(3): 1-278. (Jerusalem: Israel Program for Scientific Translation. Published for the National Science Foundation and Smithsonian Institution, Washington, D.C.), English translation, 1962.]

Marques F, Pohle G. 1995. Phylogenetic analysis of the Pinnotheridae (Crustacea, Brachyura) based on larval morphology, with emphasis on the Dissodactylus species complex. Zool. Scr. 24: 347-364.

Marques F, Pohle G. 1998. The use of structural reduction in phylogenetic reconștruction of decapods and a phylogenetic hypothesis for 15 genera of Majidae: testing previous larval hypotheses and assumptions. Invert. Reprod. Develop. 33: 241-262.

Martin JW, Abele LG. 1986. Phylogenetic relationships of the genus Aegla (Decapoda: Anomura: Aeglidae), with comments on anomuran phylogeny. J. Crust. Biol. 6: 576-616.

Martin JW, Davis GE. 2001. An updated classification of the Recent Crustacea. Nat. Hist. Mus. Los Angeles Co., Sci. Ser. 39: 1-124.

McLaughlin PA. 1974. The hermit crabs (Crustacea Decapoda, Paguridea) of northwestern North America. Zool. Verh. Leiden 130: 1-396.

McLaughlin PA. 1983. Hermit crabs-Are they really polyphyletic? J. Crust. Biol. 3: 608-621.

McLaughlin PA. 1997. Crustacea Decapoda: Hermit crabs of the family Paguridae from the KARUBAR cruise in Indonesia. In: Crosnier A, Bouchet P. (eds). Résultats des Campagnes MUSORSTOM, 16. Mém. Mus. Natn. Hist. Nat. 172: 433-572.

McLaughlin PA. 2000. Megalopal and early crab stages of Porcellanopagurus edwardsi Filhol (Decapoda: Anomura: Paguridea). Proc. Biol. Soc. Wash. 113: 721-730.

McLaughlin PA, Forest J. 1999. Hermit crabs of the genus Pagurus Fabricius (Crustacea: Decapoda: Paguridae) from southeastern South Africa. Ann. So. Afr. Mus. 105: 297-344.

McLaughlin PA, Gore R.H. 1988. Studies on the provenzanoi and other pagurid groups: I. The larval stages of Pagurus maclaughlinae García-Gómez, 1982 (Decapoda: Anomura: Paguridae) reared under laboratory conditions. J. Crust. Biol. 8: $247-277$.

McLaughlin PA, Gore RH. 1992. Studies on the provenzanoi and other pagurid groups: VII. The zoeal and megalopal stages of Pagurus armatus (Dana) (Decapoda: Anomura: Paguridae) reared in the laboratory. J. Crust. Biol. 12: 448463. 
McLaughlin PA, Lemaitre R. 1997. Carcinization - fact or fiction? I. Evidence from adult morphology. Contrib. Zool. 67(2): 79-123.

McLaughlin PA, Lemaitre R. 2001. Aspects of evolution in the anomuran superfamily Paguroidea: one larval prospective. Invert. Reprod. Develop. 38: 159-169.

McLaughlin PA, Paul JM. 2002. Abdominal tergite and pleopod changes in Lithodes aequispinus Benedict, 1895 (Decapoda: Anomura: Lithodidae) from megalopa to juvenile. Proc. Biol. Soc. Wash. 115: 138-147.

McLaughlin PA, Anger K, Kaffenberger A, Lovrich GA. 2001. Megalopal and early juvenile development in Lithodes santolla (Molina) (Decapoda: Anomura: Paguroidea: Lithodidae), with notes on zoeal variation. Invert. Reprod. Develop. 40: 53-67.

McLaughlin PA, Anger K, Kaffenberger A, Lovrich GA. 2003. Larval and early juvenile development in Paralomis granulosa (Jacquinot) (Decapoda: Anomura: Paguroidea: Lithodidae), with emphasis on abdominal changes in megalopal and crab stages. J. Nat. Hist. 37: 1433-1452.

McLaughlin PA, Crain JA, Gore RH. 1992. Studies on the provenzanoi and other pagurid groups: VI. Larval and early juvenile stages of Pagurus ochotensis (Brandt) from the eastern North Pacific reared under laboratory conditions. $J$. nat. Hist. 26: 507-531.

McLaughlin PA, Gore RH, Buce WR. 1989. Studies on the provenzanoi and other pagurid groups: III. The larval and early juvenile stages of Pagurus kennerlyi (Stimpson) (Decapoda: Anomura: Paguridae), reared in the laboratory. J. Crust. Biol. 9: 626-644.

McLaughlin PA, Gore RH, Harvey AW. 1991a. Studies on the provenzanoi and other pagurid groups: IV. The larval stages of Pagurus vetaultae Harvey and McLaughlin, 1991 (Decapoda: Anomura: Paguridae) reared in the laboratory. $J$. Crust. Biol. 11: 277-291.

McLaughlin PA, Gore RH, Harvey AW. 1991b. Studies on the provenzanoi and other pagurid groups: V. The larval stages of Pagurus arenisaxatilis Harvey and McLaughlin, 1991 (Decapoda: Anomura: Paguridae), reared in the laboratory. J. Crust. Biol. 11: 416-431.

McLaughlin PA, Siddiqui FA, Crain JA. 1993. Larval and early juvenile development in Pagurus stevensae Hart, 1971 (Decapoda: Anomura: Paguridae) reared in the laboratory. $J$. Crust. Biol. 13: 322-342.

Meier R. 1997. A test and review of the empirical performance of the ontogenetic criterion. Syst. Biol. 46: 699-721.

Mertin H. 1941. Decapode Krebse aus dem subhercynen und braunschweiger Emscher und Untersenon sowie Bemerkungen über einige verwandte Formen in der ober Kreide. Nova Act Leopoldina F.F 10: 147-264.

Miers EJ. 1876. Descriptions of some new species of Crustacea, chiefly from New Zealand. Ann. Mag. Nat. Hist. (4)17: 218-229.

Miers EJ. 1879. On a collection of Crustacea made by Capt. H.C. St. John, R.N., in the Corean and Japanese Seas. Part I. Podophthalmia. With an appendix by Capt. H.C. St. John. Proc. Zool. Soc. Lond. 1879: 18-61.

Miller PE, Coffin HG. 1961. A laboratory study of the devel- opmental stages of Hapalogaster Mertensii [sic] (Brandt), (Crustacea, Decapoda). Walla Walla Coll. Publs. Dep. Biol. Sci. 30: 1-20.

Milne-Edwards A. 1880. Report on the results of dredging, under the supervision of Alexander Agassiz, in the Gulf of Mexico, and in the Caribbean Sea, 1877, 78, 79, by the United States Coast Survey steamer "Blake", Lieut.-Commander C.D. Sigsbee, U.S.N., and Commander J.R. Bar-tlett, U.S.N., commanding. VIII. Études préliminaires sur les Crustacés. Bull. Mus. Comp. Zool. 8(1): 1-68.

Milne-Edwards A, Bouvier E-L. 1892. Observations préliminaires sur les paguriens recueillis par les expéditions du Travailleur et du Talisman. Annls. Sci. Nat. (7)13: 185226.

Milne-Edwards A, Bouvier E-L. 1894. Troisème campagne du yacht l'Hirondelle, 1887. Neolithodes. Genre nouveau de la sous-famille des Lithodinés. Bull. Soc. Zool. Fr. 1894: 120122.

Milne Edwards H. 1837. Histoire naturelle des Crustacés, comprenant l'anatomie, la physiologie et la classification de ces animaux, 2: 1-532. Paris: Librairie Encyclopédique de Roret.

Milne Edwards H, Lucas H. 1841. Description des Crustacés nouveaux ou peu connus conservés dans la collection du Muséum d'Histoire Naturelle. Archs. Mus. Natn. Hist. Nat. Paris 2: 461-483.

Minelli A, Schram FR. 1994. Owen revisited: a reappraisal of morphology in evolutionary biology. Bijd. Dierk. 64(2): 6574.

Miyake S. 1978. The crustacean Anomura of Sagami Bay. 1200 (English), 1-161 (Japanese). Tokyo: Hoikusha Publishing Co.

Molina GI. 1782. Saggio sulla storia naturale del Chili. 367 pp. Bologna.

Morgan GJ. 1987. Abbreviated development in Paguristes frontalis (Milne Edwards, 1836) (Anomura: Diogenidae) from southern Australia. J. Crust. Biol. 7: 536-540.

Morrison CL, Harvey AW, Lavery S, Tieu K, Huang Y, Cunningham CW. 2002. Mitochondrial gene rearrangements comfirm the parallel evolution of the crab-like body form. Proc. Roy. Soc. Lond. 269: 345-350.

Müller F. 1863. On the transformations of the Porcellanae. Ann. Mag. Nat. Hist. (3)11: 47-50.

Nakasone Y. 1988. Larval stages of Coenobita purpureus Stimpson and $C$. cavipes Stimpson reared in the laboratory and survival rates and growth factors of three land hermit crab larvae (Crustacea: Anomura). Zool. Sci. 5: 1105-1120.

Nelson G. 1973a. The higher-level phylogeny of vertebrates. Syst. Zool. 22: 87-91.

Nelson G. 1973b. Negative gains and positive losses: a reply to J.G. Lundberg. Syst. Zool. 22: 330.

Nelson G. 1978. Ontogeny, phylogeny, paleontology, and the biogenetic law. Syst. Zool. 27: 324-345.

Nelson G. 1985. Outgroups and Ontogeny. Cladistics 1: 29-46.

Neville AC. 1976. Animal Asymmetry. Inst. Biol. Stud. Biol. 67: $1-60$.

Ng PKL, Clark PF. 2000. The eumedonid file: a case study of systematic compatibility using larval and adult characters 
(Crustacea: Decapoda: Brachyura). Invert. Reprod. Develop. 38: 225-252.

O'Grady RT. 1985. Ontogenetic sequences and the phylogenetics of parasitic flatworm life cycles. Cladistics 1: 159170.

Oppenheimer JM. 1974. Asymmetry revisited. Am. Zool. 14 867-879.

Ortmann A. 1892. Die Decapoden-Krebse des Strassburger Museum, mit besonderer Berücksichtigung der von Herrn Dr. Döderlein bei Japan und bei den Liu-Kiu-Inseln gesammelten und zur Zeit im Strassburger Museum aufbewahrten Formen. IV. Die Abtheilungen Galatheidea und Paguridea. Zool. Jb. Syst. 6: 241- 326.

Palmer AR. 1994. Fluctuating asymmetry analyses: a primer. 335-364. In: Markow TA. (ed.). Developmental Instability: Its Origins and Evolutionary Implications: Dordrecht, The Netherlands: Kluwer Academic Publishers.

Palmer AR. 1996. From symmetry to asymmetry: Phylogenetic patterns of asymmetry variation in animals and their evolutionary significance. Proc. Natn. Acad. Sci. USA 93: 1427914286.

Panchen AL. 1992. Classification, Evolution and the nature of Biology. 403 pp. Cambridge: Cambridge University Press.

Patterson C. 1994. Null or minimal models. 173-192. In: Scotland RW, Siebert DJ, Williams DM. (eds.). Models in Phylogeny Reconstruction: Oxford: Claredon Press.

Patterson C. 1996. Comments on Mabee's "empirical rejection of the ontogenetic polarity criterion". Cladistics 12: 147-167.

Paul DH. 1989. A neurophylogenist's view of decapod Crustacea. Bull. Mar. Sci. 45: 487-506.

Paul R, Sankolli KN, Shenoy S. 1993. Juvenile morphology and appearance of sexual apppendages in two porcellanid crabs, Petrolisthes rufescens (Heller, 1861) and Pisidia gordoni (Johnson, 1970) (Decapoda, Anomura, Porcellanidae). Crustaceana 65: 346-357.

Paul DH, Then AM, Magnuson DS. 1985. Evolution of the telson neuromusculature in decapod Crustacea. Biol. Bull. 168: 106-124.

Pike RB, Williamson DI. 1960. Larvae of decapod Crustacea of the families Diogenidae and Paguridae from the Bay of Naples. Pubbl. Sta. Zool. Napoli 31: 493-552.

Pohle G. 1989. Gill and embryo grooming in lithodid crabs: Comparative functional morphology based on Lithodes maja Crust. Issues 6: 75-94.

Powar CB. 1969. Musculature of the eyestalk in Crustacea. Acta Zool. 50: 127-141.

Provenzano AJ Jr. 1962. The larval development of the tropical land hermit Coenobita clypeatus (Herbst) in the laboratory. Crustaceana 4: 207-228.

Provenzano AJ Jr. 1967. The zoeal stages and glaucothoe of the tropical eastern Pacific hermit crab Trizopagurus magnificus (Bouvier,1898) (Decapoda; Diogenidae), reared in the laboratory. Pac. Sci. 21: 457-473.

Provenzano AJ Jr. 1968a. The complete larval development of the West Indian hermit crab Petrochirus diogenes (L.) (Decapoda, Diogenidae) reared in the laboratory. Bull: Mar. Sci. 18: 143-181.

Provenzano AJ Jr. 1968b. Biological investigations of the deep sea. 37. Lithopagurus yucatanicus, a new genus and species of hermit crab with a distinctive larva. Bull. Mar. Sci. 18: 627-644.

Provenzano AJ Jr. 1971. Zoeal development of Pylopaguropsis atlantica Wass, 1963, and evidence from larval characters of some generic relationships within the Paguridae. Bull. Mar. Sci. 21: 237-267.

Provenzano AJ Jr. 1978. Larval development of the hermit crab, Paguristes spinipes Milne-Edwards, 1880 (Decapoda, Diogenidae) reared in the laboratory. Bull. Mar. Sci. 28:512526.

Provenzano AJ Jr, Rice AL. 1964. The larval stages of Pagurus marshi Benedict (Decapoda, Anomura) reared in the laboratory. Crustaceana 7: 217-235.

Provenzano AJ Jr, Rice AL. 1966. Juvenile morphology and the development of taxonomic characters in Paguristes sericeus Milne-Edwards (Decapoda, Diogenidae). Crustaceana 10: 53-69.

Przibram H. 1905. Die "Heterochelie" bei decapoden Crustaceen (zugleich: Experimentelle Studien über Regeneration. III). Arch. Entwick. 19: 181-247.

de Queiroz K. 1985. The ontogenetic method for determining character polarity and its relevance to phylogenetic systematics. Syst. Zool. 34: 280-299.

Rabalais NN, Gore RH. 1985. Abbreviated development in decapods. Crust. Issues 2: 67-126.

Rathbun MJ. 1901. Footnote in - Willey, Recent papers relating to the fauna of the Bermudas. Am. J. Sci. (4)11(64): 328.

Rathke H. 1842. Beiträge zur vergleichenden anatomie und physiology, Reisebemerkungen aus Skandinavien, nebst einem Anhange über die Rückschreitende Metamorphose der Thiere. 2. Zur Entwickelungs-Geschichte der Dekapoden. Neueste Schr. Naturf. Ges. Danzig 3(4): 23-55.

Reese ES, Kinzie RA. 1968. The larval development of the coconut or robber crab Birgus latro (L.) in the laboratory (Anomura, Paguridea). Crustaceana Suppl. 2: 117-144.

Rice AL. 1980. Crab zoeal morphology and its bearing on the classification of the Brachyura. Trans. Zool. Soc. Lond. 35: 271-424.

Rice AL. 1983. Zoeal evidence for brachyuran phylogeny. Crust. Issues 1: 313-329.

Rice AL. 1988. The megalopa stage in majid crabs, with a review of spider crab relationships based on larval characters. 27-46. In: Fincham AA, Rainbow PS. (eds.). Aspects of decapod crustacean biology. Symp. Zool. Soc. Lond. 59.

Rice AL, Provenzano AJ Jr. 1965. The zoeal stages and the glaucothöe of Paguristes sericeus A. Milne Edwards (Anomura, Diogenidae). Crustaceana 8: 239-254.

Richter S, Scholtz G. 1994. Morphological evidence for a hermit crab ancestry of lithodids (Crustacea, Decapoda, Anomala, Paguroidea). Zool. Anz. 223: 187-219.

Rodrigues LJ, Dunham EW, Coates KA. 2002. The effects of shelter type on uropod symmetry in Calcinus verrilli (sic) (Anomura: Diogenidae). J. Crust. Biol. 22: 298-303.

Russell ES. 1962. The diversity of animals. An evolutionary study. Acta Biotheor. 11: 1-151.

Saito T, Konishi K. 2002. Description of the first stage zoea of the symmetrical hermit crab Pylocheles mortensenii (Boas, 
1926) (Anomura, Paguridae, Pylochelidae). Crustaceana 75 $621-628$.

de Saint Laurent M, McLaughlin PA. 2000. Superfamily Paguroidea, family Paguridae. In: Forest J, de Saint Laurent M, McLaughlin PA, Lemaitre R. The marine fauna of New Zealand: Paguridea (Decapoda: Anomura) exclusive of the Lithodidae. NIWA Biodiversity Mem. 114: 104-209.

de Saint Laurent-Dechancé M. 1966. Remarques sur la classification de la famille des Paguridae et sur la position systématique d'Iridopagurus de Saint Laurent. Diagnose d'Anapagrides gen. nov. Bull. Mus. Natn. Hist. Nat. (2)38(3): 257-265.

Sandberg L, McLaughlin PA. 1998. Crustacea, Decapoda, Paguridae. In: Marine Invertebrates of Scandinavia, 10: 1113.

Sankolli KN, Shenoy S. 1975. Laboratory culture of the hermit crab Diogenes avarus Heller (Crustacea, Decapoda, Anomura). Bull. Dept. Mar. Sci. Univ. Cochin 7: 293-308.

Sars GO. 1890. Bidrag til Kundskaben om Decapodernes Forvandlinger. II. Lithodes-Eupagurus-SpiropagurusGalathodes-Galathea-Munida-Porcellana (Nephrops). Arch. Math. Naturvidensk. 1888: 133-201.

Sato S. 1958. Studies on larval development and fishery biology of king crab, Paralithodes camtschatica (Tilesius). Bull. Hokkaido Reg. Fish. Res. Lab. 17: 1-103.

Schalfeew P. 1892. Carcinologische Bemerkungen aus dem Zoologischen Museum der Kaiserlichen Akademie der Wissenschaften. Bull. Acad. Sci. St. Pétersbourg 35: 331342.

Schminke HK. 1981. Adaptation of Bathynellacea (Crustacea, Syncarida) to life in the interstitial (Zoea Theory). Int. Revue Ges. Hydrobiol. 66: 574-637.

Schmitt WL. 1933. Four new species of decapod crustaceans from Porto Rico. Amer. Mus. Novit. 662: 1-9.

Scholtz G. 2000. Evolution of the nauplius stage in malacostracan crustaceans. J. Zool. Syst. Evol. Res. 38: 175-187.

Scholtz G, Richter S. 1995. Phylogenetic systematics of the reptantian Decapoda (Crustacea, Malacostraca). Zool. J. Linn. Soc. 113: 289-328.

Shenoy S, Sankolli KN. 1971. On the lifehistory of a porcellanid crab, Petrolisthes lamarckii (Leach) as observed in the laboratory. J. Mar. Biol. Assoc. India 17: 147-159.

Shenoy S, Sankolli KN. 1993. Larval development of the hermit crab Diogenes miles (Herbst, 1791) [sic] (Decapoda, Anomura, Diogenidae) in the laboratory. Crustaceana 65: 253-264.

Shirley TC, Zhou S. 1997. Lecithotrophic development of the golden king crab Lithodes aequispinus (Anomura: Lithodidae). J. Crust. Biol. 17: 207-216.

Siddiqui FA, McLaughlin PA, Crain JA. 1991. Larval development of Clibanarius antillensis Stimpson, 1859 (Crustacea: Anomura: Diogenidae) reared under laboratory conditions: A comparison between Panamanian and Brazilian populations. J. Nat. Hist. 25: 917-932.

Siddiqui FA, McLaughlin PA, Crain JA. 1993. Larval development of Clibanarius albidigitus (Crustacea: Anomura: Diogenidae) reared under laboratory conditions. Mar. Biol. 116: 603-613.
Slack JMW, Holland PWH, Graham CP. 1993. The zootype and the phylotypic stage. Nature 361: 490-492.

Sluys R. 1989. Rampant parallelism: an appraisal of the use of nonuniversal derived character states in phylogenetic reconstruction. Syst. Zool. 34: 350-370.

Sternberg $R$ von. 1996. Carcinization as an underlying synapomorphy for the decapod crustacean taxon Meiura. Evol. Theory 11: 153-162.

Stevens BA. 1927. Orthopagurus, a new genus of Paguridae from the Pacific coast. Publs. Puget Sound Biol. Stn. 5: 245252.

Stimpson W. 1860. Notes on North American Crustacea, in the Museum of the Smithsonian Institution. No. II. Ann. Lyceum Nat. Hist. New York 7: 176-246 (preprint of 1862 journal paper).

Stimpson W. 1864. Descriptions of new species of marine invertebrates from Puget Sound, collected by the naturalists of the North-west Boundary Commission, A. H. Campbell, Esq., Commissioner. Proc. Acad. Nat. Sci. Philad. (2)1864: 153161.

Stüder Th. 1883. Verzeichnis der während der Crustaceen, welche während der Reise S.M.S. "Gazelle' an der Westküste von Afrika, Ascension un dem Cap der Guten Hoffnung gesammelten Crustaceen. Abh. Akad. Wiss. Berlin (1882) 2: $1-32$.

Swofford DL. PAUP*. Phylogenetic analysis using parsimony (*and other methods). Version 4. Sunderland, MA: Sinauer Associates.

Swofford DL, Olsen GJ, Waddell PJ, Hillis DM. 1996. Phylogenetic inference. 407-514. In: Hillis DM, Moritz C, Mable BK. (eds.). Molecular systematics: Sunderland MA: Sinauer Associates, Inc.

Thompson MT. 1903. The metamorphosis of the hermit crab. Proc. Boston Soc. Nat. Hist. 31(4): 147-209.

Tilesius WC. 1815. De Cancris Camtschaticis, Oniscis, Entomostracis et Cancellis marinis microscopicis noctilucentibus, Cum tabulis IV: Aenacis et appendice adnexo de acaris et Ricinis Camtschaticis. Auctore Tilesio. Conventui exhibuit die 3 Februarii 1813. Mém. Acad. Sci. St. Pétersbourg 5: 331-405.

Tudge CC, Scheltinga DM, Jamieson BGM. 2001. Spermatozoal morphology in the "symmetrical" hermit crab, Pylocheles (Bathycheles) sp. (Crustacea, Decapoda, Anomura, Paguroidea, Pylochelidae). Zoosystema 23: 117-130.

Van Dover CL. 1982. Reduction of maxillary endites in larval Anomura and Brachyura. Crustaceana 43: 211-215.

Van Dover CL, Factor JR, Gore RH. 1982. Developmental patterns of larval scaphognathites: an aid to the classification of anomuran and brachyuran Crustacea. J. Crust. Biol. 2: 48-59.

Walossek D. 1993. The Upper Cambrian Rehbachiella and the phylogeny of Branchiopoda and Crustacea. Fossils Strata 32: 1-202.

Walossek D, Müller KJ. 1990. Upper Cambrian stem-lineage crustaceans and their bearing upon the monophyletic origin of the Crustacea and the position of Agnostus. Lethaia 23: 409-427. •

Walossek D, Müller KJ. 1998. Early arthropod phylogeny in 
light of the Cambrian 'Orsten' fossils. 185-231. In: Edgecombe GD (ed.) Arthropod Fossils and Phylogeny: New York: Columbia University Press:

Wear RG. 1965. Larvae of Petrocheles spinosus Meirs, 1876 (Crustacea, Decapoda, Anomura) with keys to the New Zealand porcellanid larvae. Trans. Roy. Soc. New Zealand, Zool. 5: 147-168.

Wehrtmann IS, Albornoz L, Véliz D, Pardo LM. 1996. Description of the early developmental stages, including the first crab, of Allopetrolisthes angulosus (Guérin, 1835) (Decapoda: Anomura: Porcellanidae) from Chilean waters, cultivated under laboratory conditions. J. Crust. Biol. 16: 730747.

Wheeler QD. 1990. Ontogeny and character phylogeny. Cladistics 6: 225-268.

White A. 1856. Some remarks on Crustacea of the genus Lithodes, with a brief description of a species apparently hitherto unrecorded. Proc. Zool. Soc. Lond. 24: 132-135.

Wiens JJ. 2001. Character analysis in morphological phylogenetics: Problems and solutions. Syst. Biol. 50: 689699.

Wilkinson M. 1992. Ordered versus unordered characters. Cladistics 8: 375-385.

Wilkinson M. 1995. A comparison of two methods of character construction. Cladistics 11: 297-308.

Williams DM, Scotland RW, Blackmore S. 1990. Is there di- rect ontogenetic criterion in systematics? Biol. J. Linn. Soc. 39: 99-108.

Williamson DI. 1969. Names of larvae in the Decapoda and Euphausiacea. Crustaceana 16: 210-213.

Williamson DI. 1974. Larval characters and the origin of crabs (Crustacea, Decapoda, Brachyura). Thal. Jugoslavica 10: 401-414.

Williamson DI. 1982. Larval morphology and diversity. 43110. In: Abele LG. (ed.). The Biology of Crustacea, vol. 2, Embryology, morphology and genetics: New York: Academic Press.

Williamson DI. 1988. Evolutionary trends in larval forms. 1125. In: Fincham AA, Rainbow PS. (eds.). Aspects of decapod crustacean biology. Symp.Zool. Soc. Lond. 59.

WolffT. 1961. Description of a remarkable deep-sea hermit crab with notes on the evolution of the Paguridae. Galathea Rept. 4: 11-32.

Wolpert L. 1990. The evolution of development. Biol. J. Linn Soc. 39: 109-124.

Wolpert L. 1994. The evolutionary origin of development: cycles, patterning, privilege and continuity. Development 1994 Suppl.: 79-84.

Yamaguchi S. 1938. S̈pawning and development of Coenobita rugosa. Bull. Sci. Kyushu Univ. 8: 163-177.

Received: 18 Sept. 2002 